\title{
The Gelatinous Macroplankton Community at the Hatoma Knoll Hydrothermal Vent
}

\author{
Dhugal Lindsay, Mitsuko Umetsu, Mary Grossmann, Hiroshi Miyake, \\ and Hiroyuki Yamamoto
}

\begin{abstract}
A series of dives around the Hatoma Knoll, Okinawa Trough, have revealed a diverse community of gelatinous midwater animals. Many of these animals are potential predators of the larvae of hydrothermal vent-associated organisms. Due to the lack of published information on the midwater fauna of the Okinawa Trough, this paper endeavours to present a synopsis of the macroplanktonic gelatinous faunal elements present in and around the vent site at all depths where vent larvae may occur-from the surface to the benthopelagic layer. Three pelagic tunicates, eight ctenophores, seven siphonophores, eight hydrozoan medusae and two syphozoan medusae were recognized. Taxonomic treatments and comments on distribution and ecology are provided where such information exists.
\end{abstract}

Keywords

Gelatinous zooplankton • Taxonomic guide $•$ Vent larvae predators

\subsection{Introduction}

Limited work has been done on deep-sea benthopelagic fauna, particularly the gelatinous component. In fact, even in the overlying water column, very little work has been published on the gelatinous component of the ocean's midwater zone. Data on the cnidarian community can be gathered using plankton nets but more fragile animals such as ctenophores and appendicularians, for example, are invariably destroyed past recognition. In situ observations on the gelatinous zooplankton community of the midwater

D. Lindsay $(\bowtie) \bullet H$. Yamamoto

Japan Agency for Marine-Earth Science and Technology (JAMSTEC), 2-15 Natsushima-cho, Yokosuka, Kanagawa 237-0061, Japan e-mail: dhugal@jamstec.go.jp

M. Umetsu • H. Miyake

Kitasato University, 1-15-1 Kitasato, Minami-ku, Sagamihara, Kanagawa 252-0373, Japan

M. Grossmann

Okinawa Institute of Marine Science and Technology (OIST), 1919-1 Tancha, Onna, Okinawa 904-0495, Japan zone that include these fragile components are very few and far between, with the notable exception of work done off California (Haddock and Case 1999) and around Japan (e.g. Hunt and Lindsay 1999; Vinogradov and Shushkina 2002; Toyokawa et al. 2003; Lindsay 2005; Lindsay and Hunt 2005; Lindsay and Miyake 2007), and scattered reports from the northern Atlantic (Youngbluth et al. 2008), the south-west Indian Ocean (Lindsay et al. 2000) and the Arctic Ocean (Raskoff et al. 2010). Most of these reports are from areas without active venting. Deep-sea hydrothermal plumes enable high levels of primary production by chemolithoautotrophic microbes and in some cases the amount of organic material produced can be comparable with that of settling particles originating from near the sea surface (Sunamura and Yanagawa, Chap. 3). Such organic material supply should affect the surrounding deep-sea ecosystem, however, very few previous reports exist describing the gelatinous fauna in regions of hydrothermal venting (Vereshchaka and Vinogradov 1999; Burd and Thomson 2000; Skebo et al. 2006). Although Burd and Thomson (2000) reported on the distribution and relative importance of jellyfish at the Endeavour Ridge in the north-east Pacific 
at the species level and found aggregations of the ulmarid scyphomedusa Stygiomedusa at the vent plume boundary, there was no information on the ctenophore community due to the net sampling survey method used. Both Vereshchaka and Vinogradov (1999) and Skebo et al. (2006) used in situ visual observations, which should have allowed them to gather information on the fragile ctenophores and larvaceans. However, although the former authors showed that gelatinous animals and radiolarians can dominate plankton biomass throughout the water column, particularly just above and below the main core of the hydrothermal vent plume, at the Broken Spur vent field, mid-Atlantic ridge, and the latter authors also found significant differences in jellyfish abundances between the near-field and far-field areas, the level of taxonomic resolution was only at the Phylum level. The midwater and benthopelagic fauna occurring around deep sea chemosynthetic ecosystems is therefore somewhat of a black box, even though the predation pressure on vent-derived larvae exerted by its inhabitants may be considerable. The taxonomy of these soft-bodied predators is difficult and the information needed to correctly identify many of the species is scattered throughout the literature in a variety of languages. In the present paper we analysed the video record from ten dives of the Remotely Operated Vehicle (ROV) HyperDolphin around the Hatoma Knoll hydrothermal vent site (approx. $21^{\circ} 51.45^{\prime} \mathrm{N} 123^{\circ} 50.45^{\prime} \mathrm{E}$ ) and give taxonomic treatments and other information on the gelatinous zooplankton that were observed, in order to stimulate and facilitate further work. As it is not yet known at what depths the larvae of each vent species inhabit during development, we give a synopsis of the gelatinous zooplankton that could eat released eggs and newly-hatched larvae (eg. larvaceans, lobate ctenophores) as well as those that would be expected to prey on larvae nearing their settlement phase (eg. siphonophores and cydippid ctenophores), and their potential predators, in turn. Where a video record existed, it was analyzed from the benthopelagic layers near the vent plumes right up to the near surface layer.

\subsection{Materials and Methods}

High definition video (1080i) from the ROV HyperDolphin SuperHarp high definition video camera (Lindsay 2003) was recorded on HDCAM videotapes without depth or time data superimposed. Standard video (NTSC) was recorded simultaneously on DigiBetaCam tapes with data including depth and local time superimposed as text on the video image. The video record for each dive was reviewed using the original HD-CAM tapes (Sony HDW-500 HDCam recorder, Sony HDTranslation Color Monitor PHM-14M7J) and when organisms that could be identified appeared on the screen, the timecode at which they first appeared and the timecode at which they disappeared from the screen were entered into an Excel worksheet along with the organism's taxon. The DigiBetaCam tapes were then referred to (Sony HDW-M2100 HD Digital MultiPlayer, Sony HDTranslation Color Monitor PHM-20M7J) in order to determine the local time and depth at which each organism occurred through identifying a unique video sequence on each tape as a place marker (e.g. a camera pan to the manipulator followed by a tilt to the sample basket and a jellyfish appearing at left screen) and adding/subtracting timecode values to calculate the approximate location on the DigiBetaCam tape at which the organism should be visible. This allowed the DigiBetaCam tape to be fast-forwarded to the approximate location of the organism in question, which was then searched for by eye and frames synchronized manually using the jog dial on the editing keyboard (Sony BKE-2010). Depth and local time values when the organism first appeared were then entered into the Excel worksheet. Each video sequence was captured (AJA WZZ-KiPro2400) onto a hard disk cartridge at ProRes 4:2:2HQ resolution via HD-SDI and saved in Quicktime format (.mov). Captured files were played back using Quicktime Player 7 version 7.6.6 via Firewire 800, the start and end timecodes of the captured clip noted, and the clip saved to a local hard disk with the filename format incorporating the submersible name (HD = ROV HyperDolphin), dive number, start timecode, end timecode, local time, taxon name or organism-specific identification code, taxonomist/person responsible for species ID, and common Japanese name. For example, a clip of the trachymedusa Crossota millsae from timecode 04:49:58; 13 to $04: 53: 58 ; 03$ corresponding to local time of first appearance 13:25:20 taken during dive 296 of the ROV HyperDolphin and identified by Dhugal Lindsay would be given a filename of HD29604495813to04535803-132520Crossota_millsae-Dhugal_Lindsay-KUROKURAGENONA KAMA.mov. Still images were extracted from the video files by viewing them at native magnification (Command 1 Actual Size), copying them to the clipboard (Command C Copy), creating a new file in Adobe Photoshop CS5 (version 12.0.4 $\times$ 64) with width 1,920 pixels, height 1,080 pixels and resolution 72 pixels/in., and pasting them to the blank canvas (Command P Paste). The still images were then saved as TIFF files with no compression, IBM PC Byte Order and an interleaved pixel order with the frame number incorporated into the file name (e.g. HD296-04502821Crossota_millsae-Dhugal_Lindsay-KUROKURAGENONA KAMA.tif). These file name formats were picked to act as unique identifiers for video sequences and still images that would allow the files to be linked in a database to both environmental data such as CTD data on depth, temperature and salinity, and to location data for biogeographic studies. Local time was included but not solely used in the filename as resolution would only then be possible in one second intervals, and future progress in automated image 
Table 51.1 Dives analyzed during the present study

\begin{tabular}{|c|c|c|c|c|}
\hline Dive No. & Date & Surveyed Depth & Time on video & Notes \\
\hline $2 \mathrm{~K} 1183$ & 18-May-99 & $0-1,521$ & 09:42-16:06 & Specimens studied \\
\hline $2 \mathrm{~K} 1188$ & 28-May-99 & $0-1,524$ & $09: 13-15: 57$ & Specimens studied \\
\hline HD66 & 15-Nov-01 & $1,526-1,527$ & $13: 40-15: 53$ & Near bottom only \\
\hline HD67 & 18-Nov-01 & $1,525-1,529$ & $09: 45-15: 05$ & Near bottom only \\
\hline HD225 & $15-$ Sept-03 & $0-1,520$ & $09: 25-17: 36$ & Descent at $25 \mathrm{~m} / \mathrm{min}$ \\
\hline HD226 & 16-Sept-03 & $0-1,532$ & $08: 40-17: 46$ & \\
\hline HD293 & 16-Apr-04 & $0-1,530$ & $08: 41-16: 44$ & Descent at $25 \mathrm{~m} / \mathrm{min}$ \\
\hline HD294 & 17-Apr-04 & $0-1,482$ & $17: 41-02: 14$ & \\
\hline HD295 & 20-Apr-04 & $0-1,475$ & $11: 21-18: 43$ & \\
\hline HD296 & 21-Apr-04 & $0-1,477$ & $08: 35-16: 32$ & \\
\hline HD297 & 22-Apr-04 & $0-1,528$ & $08: 40-15: 27$ & Descent at $25 \mathrm{~m} / \mathrm{min}$ \\
\hline HD708 & 30-Jun-07 & $1,472-1,480$ & $14: 14-17: 18$ & Near bottom only \\
\hline
\end{tabular}

$2 \mathrm{~K}=$ Shinkai 2000, HD=ROV HyperDolphin

recognition technologies will need frame level resolution for voucher image libraries. Low resolution video footage of the organisms is archived in the JAMSTEC E-library of Deepsea Images (J-EDI) and can be accessed through the following URL: http://www.godac.jamstec.go.jp/jedi/public/ Sec101.jsf. A "Search by Dive Information" is possible by inputting the Submersible (e.g. HYPER-DOLPHIN) and the Dive No. (e.g. 0294) in the respective fields. Footage of the entire dive has been subdivided into shorter, non-overlapping streaming video clips with unique identifier Video IDs, where the final two numerical values, subdivided by an underbar, are the "in" and "out" timecodes from the original HDCAM-recorded videotapes in the case of ROV HyperDolphin Dives 225 or later. The elapsed time window to the right of the sliding bar allows one to move to the video footage of the target organism by subtracting the streaming subclip "in" timecode value from the target filename timecode and typing that elapsed time value into the window. Full resolution video is available from JAMSTEC's Data Management Office (see http://www.godac.jamstec.go.jp/ jedi/e/readme.html\#readme_img). The video and still data from this analysis is also stored at full resolution on a Buffalo TeraStation hard disk RAID array (TS-QVH8.0TL/R6), accessible by Ethernet, at the Research and Development (R\&D) Center for Submarine Resources, JAMSTEC, and is available on request.

A total of ten dives were analyzed (Table 51.1), with four of these dives having been conducted specifically for the purpose of cataloguing the midwater fauna above the Hatoma Knoll hydrothermal vent site (HD226, HD294, HD295, HD296). Dives where the descent speed was approximately $25 \mathrm{~m} / \mathrm{min}$ (HD225, HD293, HD297) allowed the identification of very few animals, none of which were of a suitable quality to extract still images. The Shinkai $2000(2 \mathrm{~K})$ video record was in low resolution NTSC format and consequently very few taxa were identifiable to species level, although several species were captured and were examined under a stereo dissecting microscope for the present study. Three ROV HyperDolphin dives concentrated on the benthic and benthopelagic layers (HD66, HD67, HD708) with the training dive HD67 having many image sequences of a quality good enough to both identify animals to species level and to extract still images of publication quality. Environmental parameters during the dives were measured with a Seabird SBE19 CTD and SBE13 dissolved oxygen (e.g. Fig. 51.1).

A subset of the observed organisms were collected during the midwater dives using a suction sampler or gate sampler (Lindsay 2003) and photographed alive on board ship in phototanks or planktonkreisels using a digital camera. When organisms were sampled, an identifier as to which cannister or sampler were used (eg. SS1 for Suction Sampler cannister 1) and which sample from the cannister (eg. A, B, etc.) it was, were appended to the Dive Number field in the filename. If the image was a photograph rather than a framegrab then the photo filename was also appended. Terminology for the taxonomic treatments are given in Fig. 51.2.

\subsection{Results}

\subsubsection{General Synopsis}

All dives in the vicinity of the Hatoma Knoll in the JAMSTEC video archive were conducted at the hydrothermal vent site and passed through the vent plume. This confounded attempts to compare the number and types of macroplanktonic organisms between vent and non-vent sites and to gauge the possible effects of the vent plume on plankton biomass and community structure.

Large numbers of appendicularian larvaceans were observed within the highly turbid water masses associated with the vent plume but were hardly ever observed at other depths. Almost every individual exhibited the same 
Fig. 51.1 Vertical profiles of temperature (red) and salinity (blue) vs depth during ROV HyperDolphin dive 296

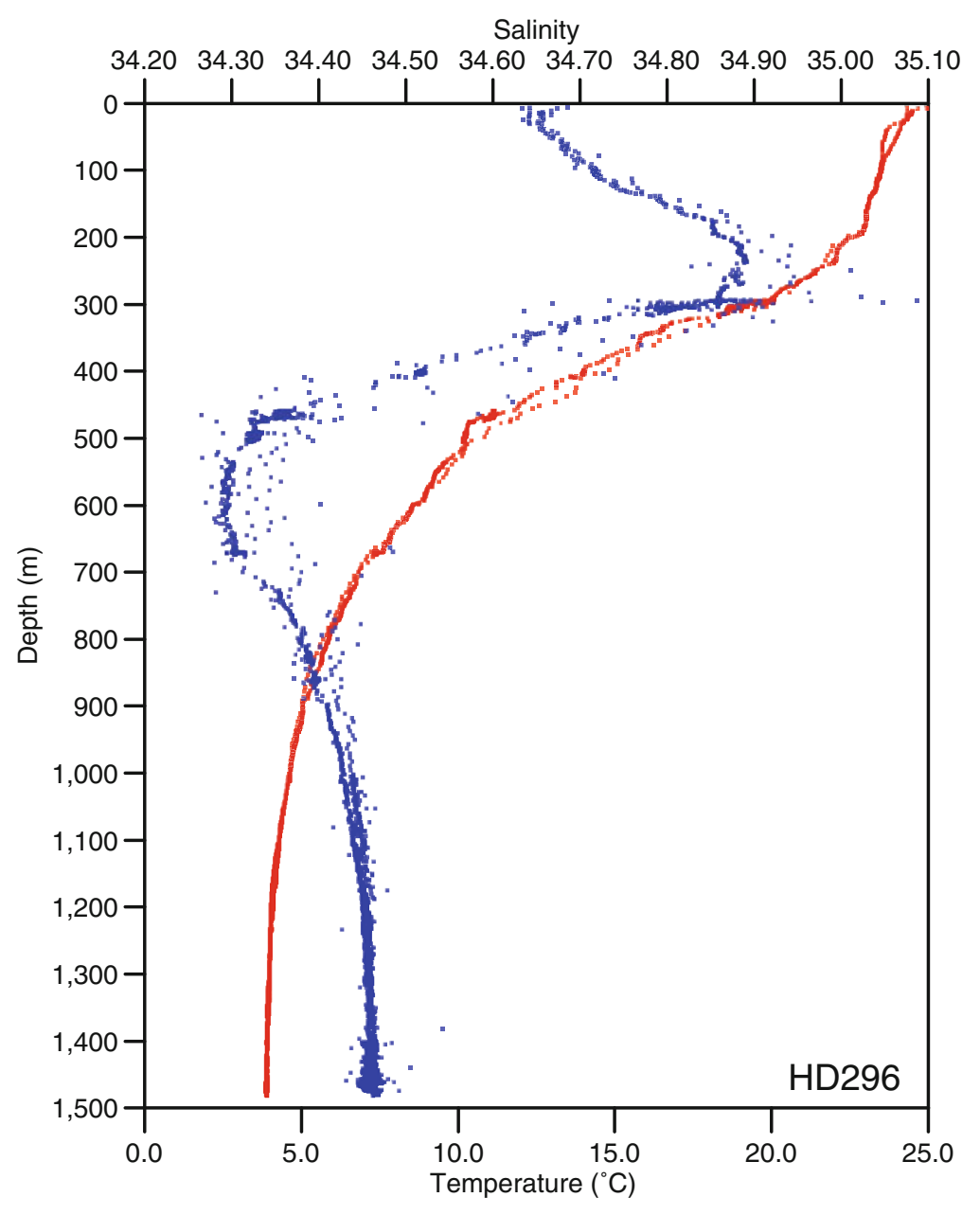

morphology of their filtering houses and the rare behavioural trait of not discarding their house and escaping when caught in the currents produced by the thrusters of the ROV (personal observations). These animals were unable to be collected due to mechanical problems with the ROV, but the house morphology observed on the video record suggests that the vent plume-associated species belongs to the larvacean family Oikopleuridae. These animals could be expected to feed either on bacterial flocs or on the early larval stages of vent animals (see below).

Narcomedusae belonging to the genus Solmissus were common below $800 \mathrm{~m}$ right up to the vent plume boundary but were not observed in the highly turbid vent plumeaffected water masses below 1,350 m. They also occurred, albeit rarely, at shallower depths. Solmissus is known to feed exclusively on gelatinous prey but whether this prey includes gelatinous appendicularian larvaceans is not known at this time.

The midwater fauna in the Okinawa Trough over the Hatoma Knoll differed considerably from that off the Sanriku Coast, in Sagami and Suruga Bays, and in the Japan
Sea. Most of the siphonophores observed were calycophorans - a result mirroring that of another subtropical oligotrophic area: the south-western Indian Ocean (Lindsay et al. 2000). In particular, clausophyid species were relatively common. Lobate ctenophores belonging to the genera Bathocyroe and Lampocteis were also observed in relatively large numbers in the deeper layers. The gelatinous macroplankton observed at the site are listed in Table 51.2.

\subsubsection{Macroplanktonic Predators Considered Capable of Preying on Vent Larvae}

Chordata

Order Copelata

Three species of larvaceans were identified within and around the vent plume. The inner filters of larvacean houses differ in mesh size on a species-specific basis with some species of the genus Oikopleura able to feed on particles as 


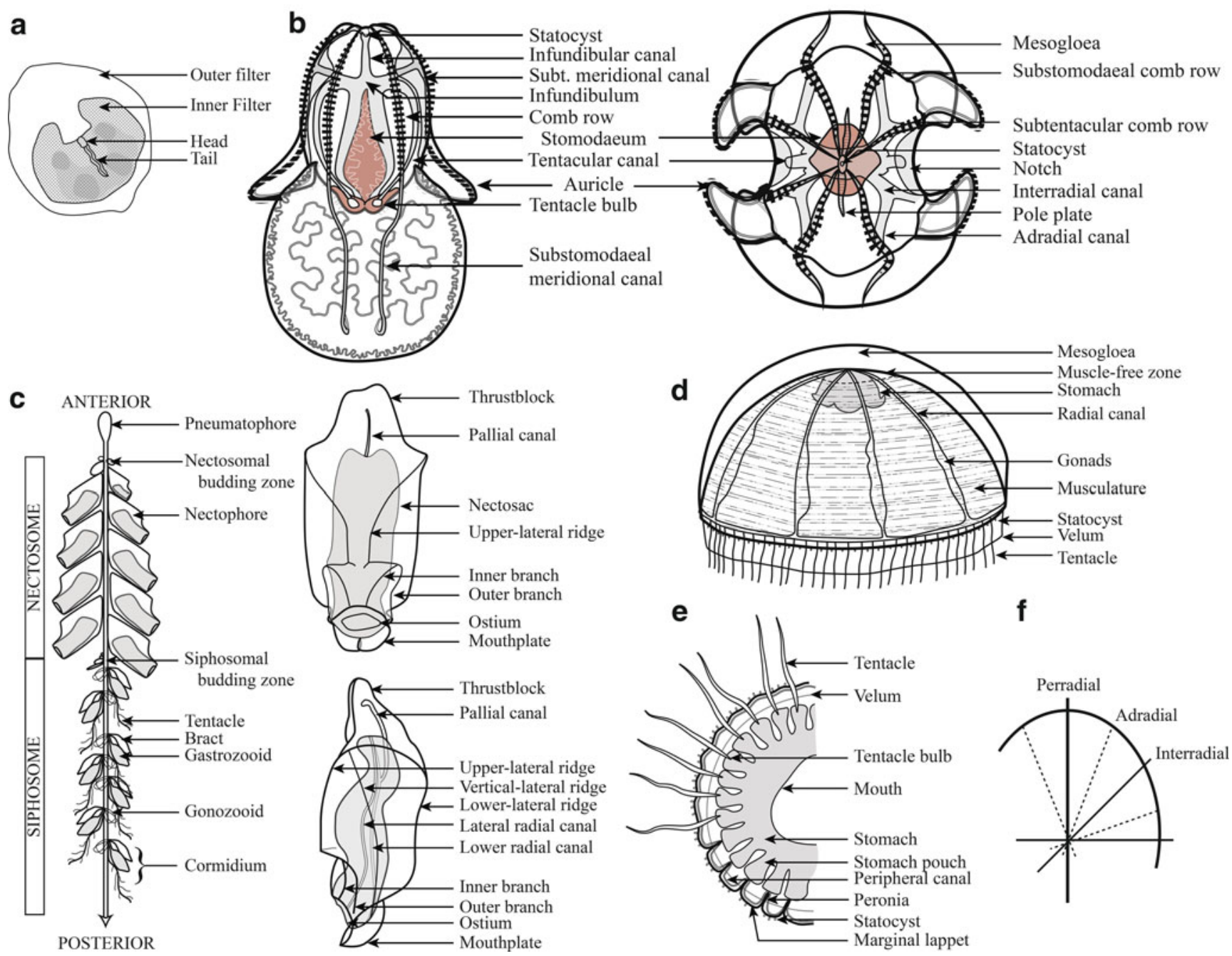

Fig. 51.2 Terminology for (a) larvacean appendicularians, (b) lobate ctenophores, (c) physonect siphonophores, (d) trachymedusae, (e) narcomedusae, and (f) the main axes of radially symmetrical animals

small as $13 \mu \mathrm{m}$ (Bone 1998), presumably allowing them to feed on the newly-released larvae of some vent species.

Family Oikopleuridae Lohmann, 1915

Subfamily Oikopleurinae Lohmann, 1896

Genus Oikopleura Mertens, 1831

Oikopleura sp. A (Fig. 51.3)

This species was identified according to the morphology of its house by Dr. Russell Hopcroft as belonging to the genus Oikopleura, with affinities to $O$. villafrancae Fenaux, 1992 (personal communication).

The distribution and abundance of this larvacean species is overlaid on a map of plume-associated turbidity in Fig. 51.4. A direct correlation between turbidity and abundance of larvacean feeding filters was not observed. However, larvacean feeding filters of this morphotype were not observed at depths shallower than $1,400 \mathrm{~m}$, where the physico-chemical signatures indicative of vent plume water were not evident. These larvaceans could conceivably be feeding directly on plume-associated bacterial flocs. However, the few values for bacterial cell density values obtained by Niskin bottle sampling did not show statistically significant correlations with oikopleurid abundances (Sunamura, personal communication). A method of mapping in situ bacterial abundances needs to be developed. If this oikopleurid species can be sampled in forthcoming surveys it is suggested that a PCR analysis of the gut contents as well as a stable isotope analysis of the musculature be attempted in order to determine whether bacteria, vent larvae, or some other organic matter source is being ingested and assimilated.

Subfamily Bathochordaeinae Lohmann, 1915

Genus Mesochordaeus Fenaux and Youngbluth, 1990

Mesochordaeus sp. A (Fig. 51.5)

House large, roughly ovoid, to $30 \mathrm{~cm}$ in length, almost five times the animal's tail length; inner filter lobed, almost filling external filter; pre-filter absent. This species was observed only at depths shallower than the hydrothermal 


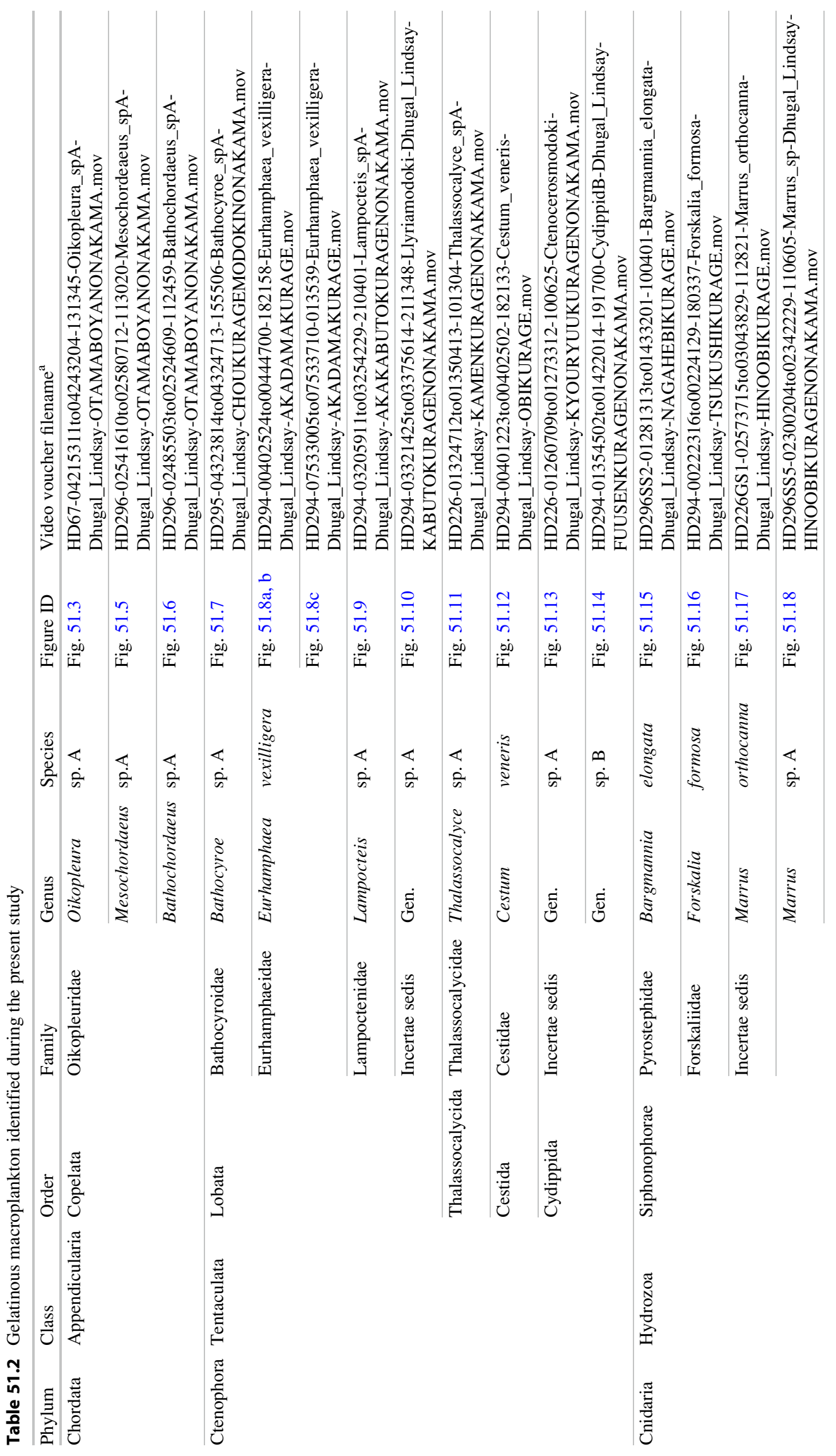



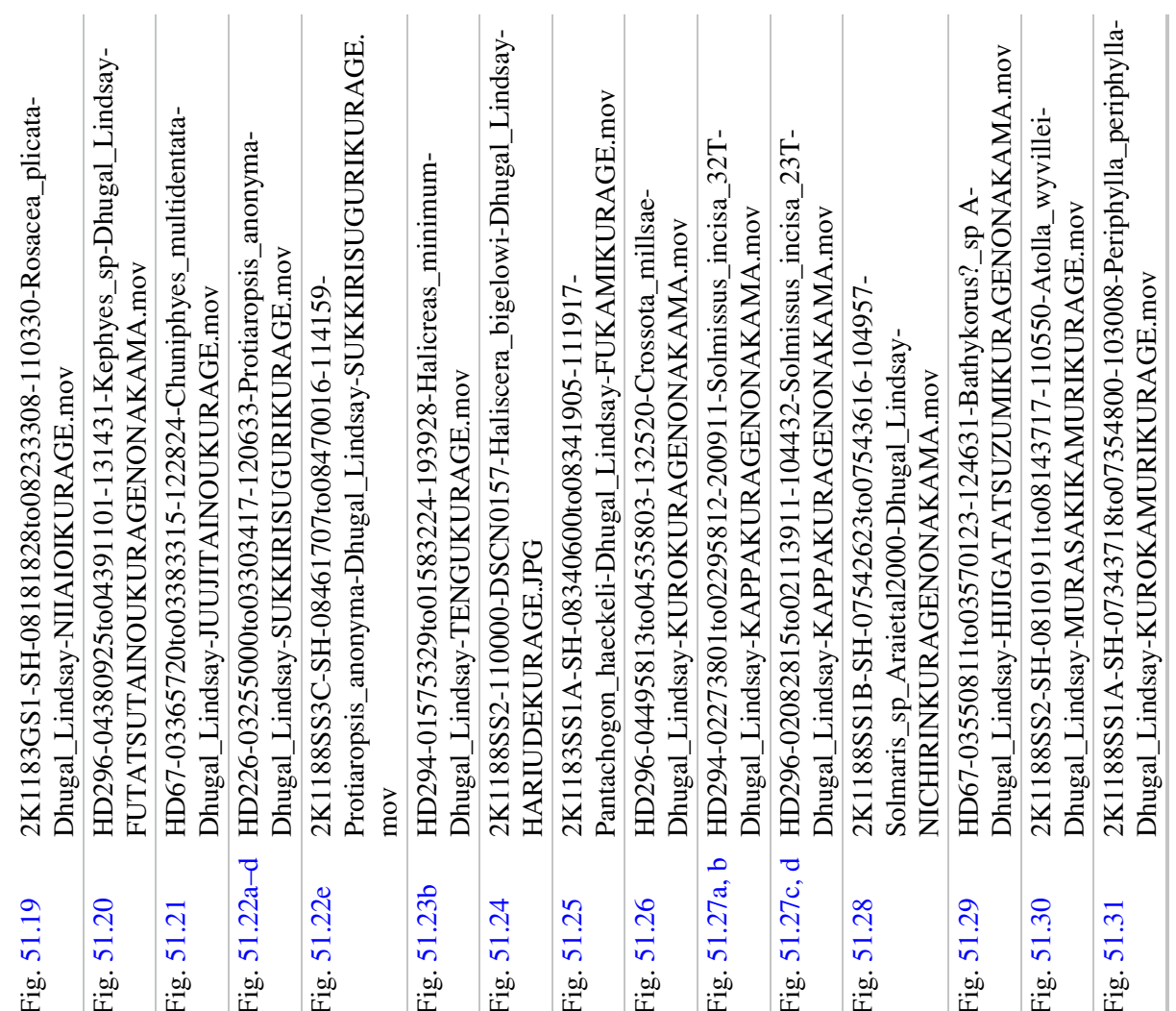

㭧 㭧
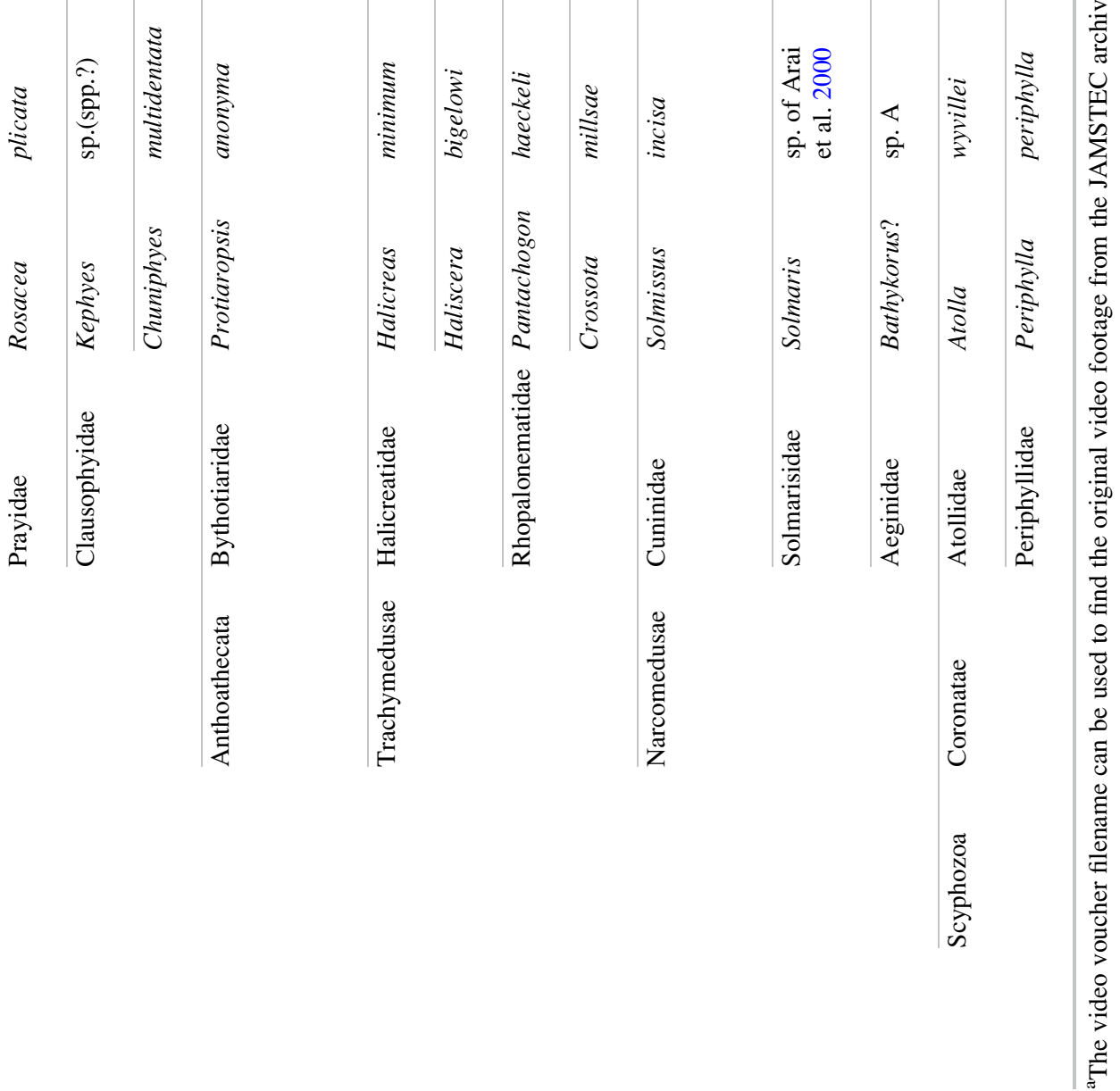


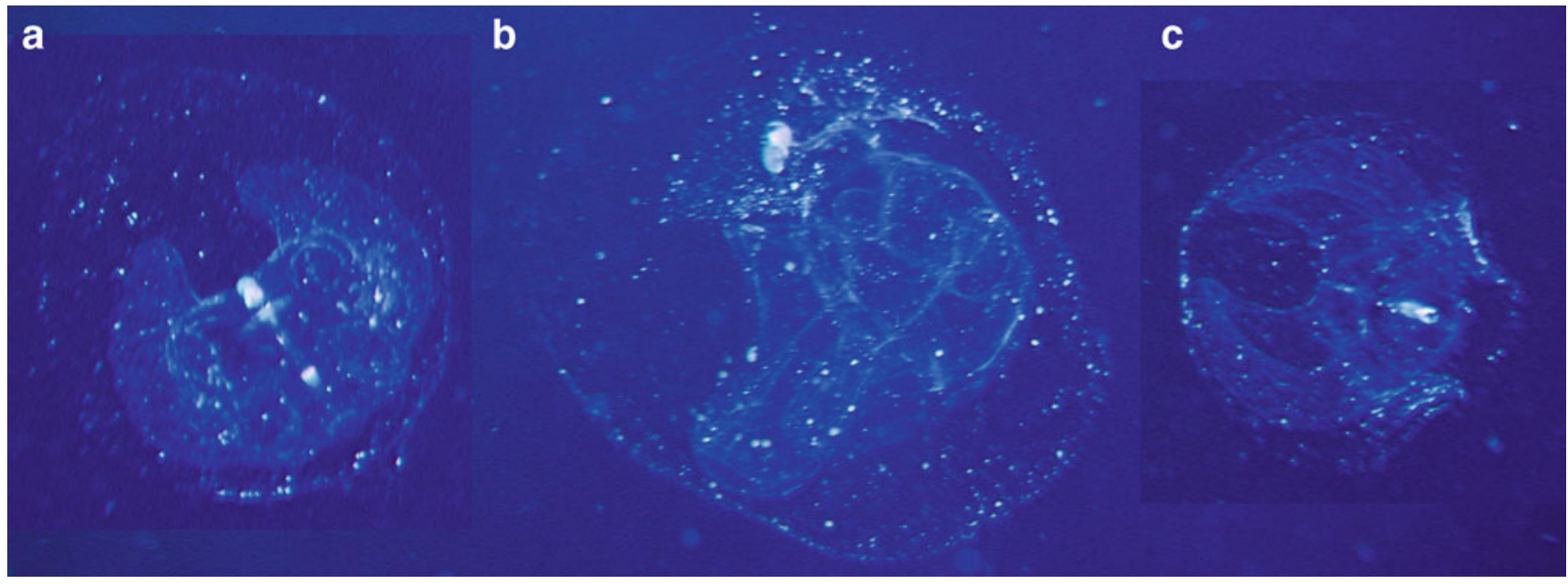

Fig. 51.3 (a) Front, (b) lateral, and (c) top views of the feeding filter "house" of the vent plume-associated larvacean observed at the Hatoma Knoll hydrothermal vent site, possibly Oikopleura villafrancae? (ID by Russ Hopcroft)

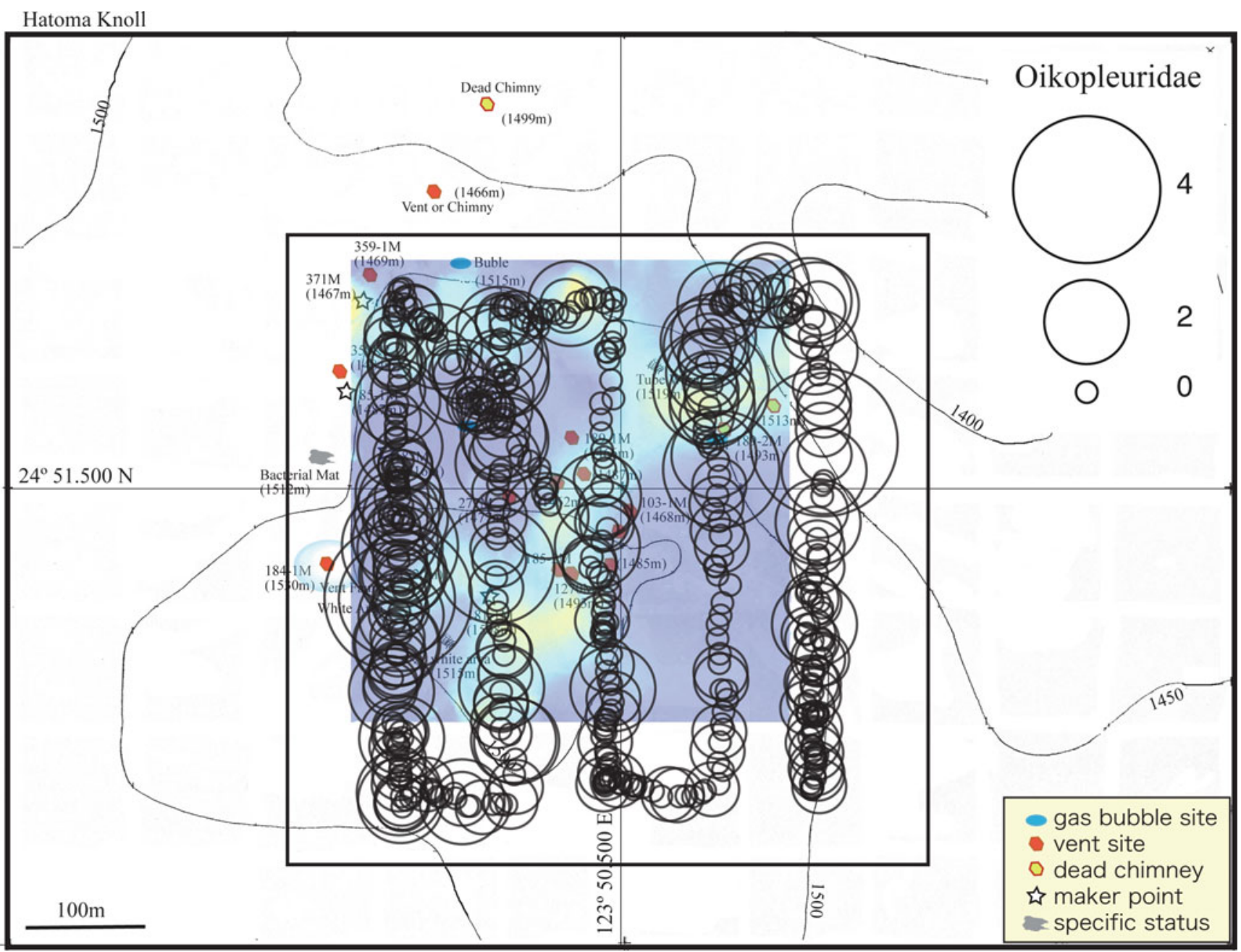

Fig. 51.4 Horizontal distribution of turbidity, a proxy for vent-derived plume water, in the $1,435 \mathrm{~m}$ depth layer $(40 \mathrm{~m}$ altitude) over the Hatoma Knoll hydrothermal vent site in the Nansei Island chain during ROV HyperDolphin Dive HD295, April 2004. Black circles represent the number of oikopleurid larvacean tunicates observed per minute with the maximum abundance being 12 animals per minute. Warm colours indicate areas of highest turbidity 
Fig. 51.5 Mesochordaeus sp. A observed at $851 \mathrm{~m}$ depth during ROV HyperDolphin dive 296

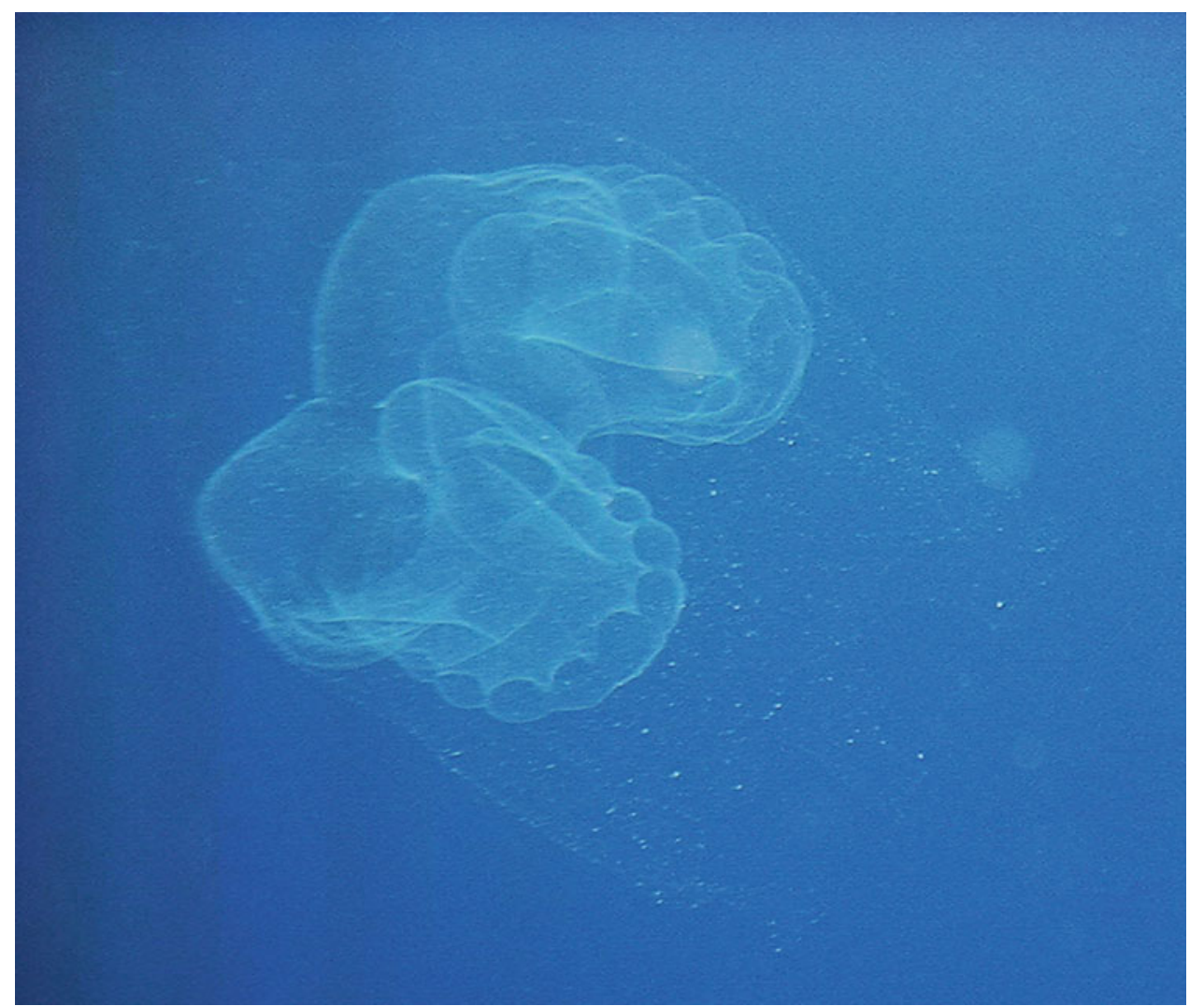

vent plume, such as $851 \mathrm{~m}$ for the figured animal observed during dive HD296.

Genus Bathochordaeus Chun, 1900

Bathochordaeus sp. A (Fig. 51.6)

House large, roughly ovoid, to $2 \mathrm{~m}$ length, almost eighty times the animal's tail length; inner filter much smaller than outer filter; pre-filter absent. This species was also only observed only at depths shallower than the hydrothermal vent plume such as $819 \mathrm{~m}$ for the figured animal observed during dive HD296. Two species are currently described in this genus.

\section{Ctenophora}

Order Lobata Agassiz, 1860

Lobate ctenophores feed by trapping particles on their oral lobes using mucous or sticky colloblast cells, allowing them to feed on a wide range of particle sizes, including extremely small particles such as, presumably, newlyreleased vent animal larvae.

Family Bathocyroidae Madin and Harbison, 1982

Genus Bathocyroe Madin and Harbison, 1982

Bathocyroe sp. A (Fig. 51.7)

Body with a pair of muscular, bowl-like lobes at oral end, body surface smooth, slightly compressed in tentacular plane; with tentacle bulbs positioned near aboral end of stomodaeum, within tentacle sheaths; stomodaeum often darkly pigmented; with four large, elongate, ciliated auricles, positioned well aboral of the mouth; four interradial canals arising from infundibular canal and supplying adradial canals, which connect to meridional canals at their aboral ends; paragastric canals present, with diverticula, branching at mouth before running towards distalmost edge of oral lobes; subtentacular meridional canals united orally to branches of paragastric canals at distalmost edge of oral lobes; substomodaeal meridional canals looping within lobes, connecting orally to adjacent subtentacular meridional canals at distalmost margin of oral lobes.

Comments: At least some species of Bathocyroe are capable of vigorous swimming by flapping their oral lobes together in a frogkick motion. The original description of $B$. fosteri Madin and Harbison, 1978 is misleading as to the position of the auricles relative to the stomach, appearing as if they start at the level of the mouth in Fig. 1 (Madin and Harbison 1978a), which they do not. It also states that the subtentacular meridional canals in each oral lobe are connected with each other at the distalmost edge of the oral lobe but the present authors believe a groove may have been mistaken for a canal in the original description as none of the other two described Bathocyroe species $(B$. paragaster (Ralph and Kaberry, 1950) and B. longigula Horita et al., 2011) or three undescribed species show this character (personal observation). The Bathocyroe species observed at the Hatoma Knoll seems most similar 
Fig. 51.6 Bathochordaeus sp. A observed at $819 \mathrm{~m}$ depth during ROV HyperDolphin dive 296

Fig. 51.7 Bathocyroe sp. A observed at $1,400 \mathrm{~m}$ depth during ROV HyperDolphin dive 295
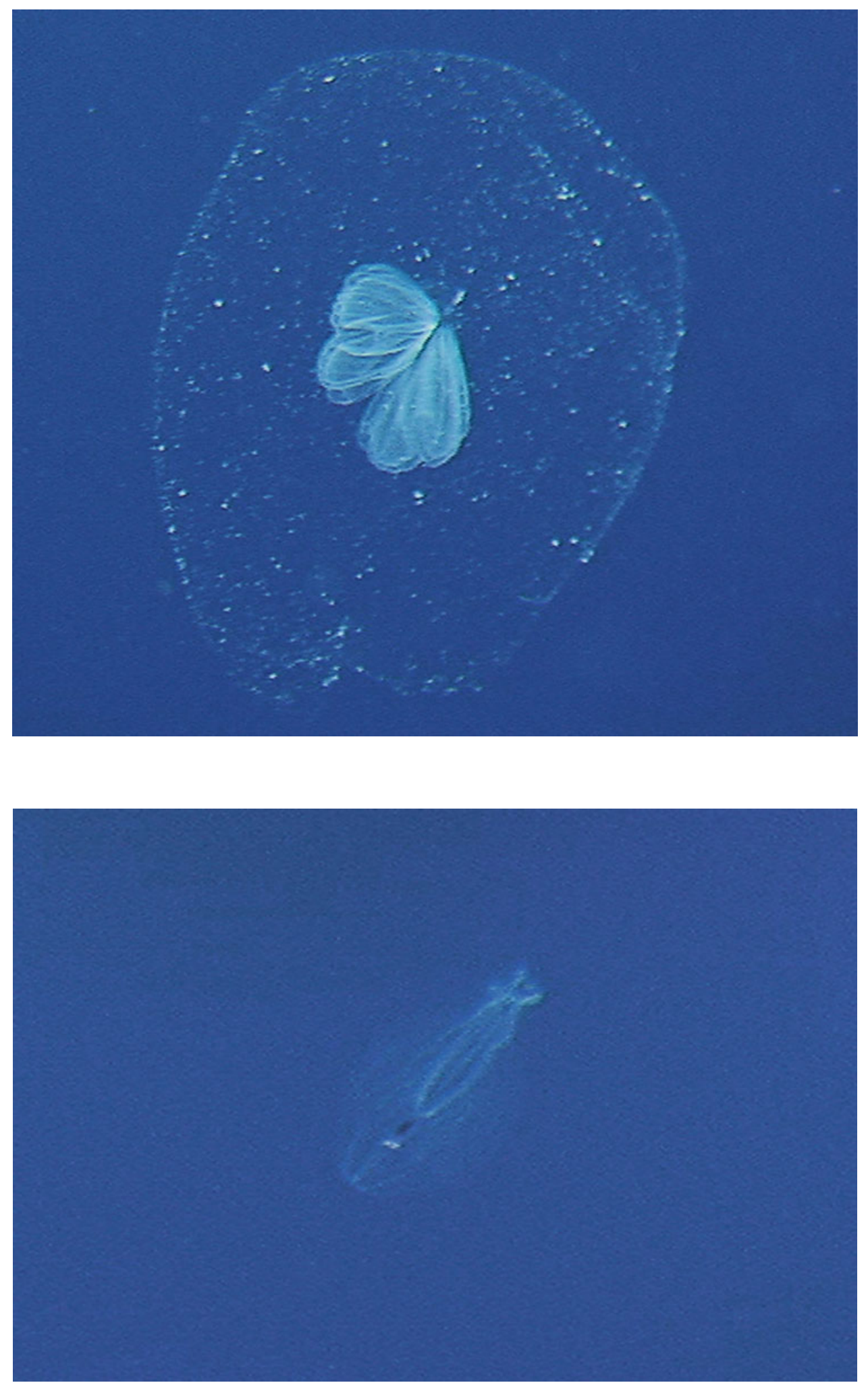

morphologically to B. fosteri. Bathocyroe species have been observed floating with their oral lobes upwards and cupped in a generally conical morphology reminiscent of a sediment trap (personal observations). Such an attitude would be conducive to the collection of sinking marine snow and its associated fauna, as well as to benthic larvae entering the settlement phase.

Family Eurhamphaeidae L. Agassiz, 1860 


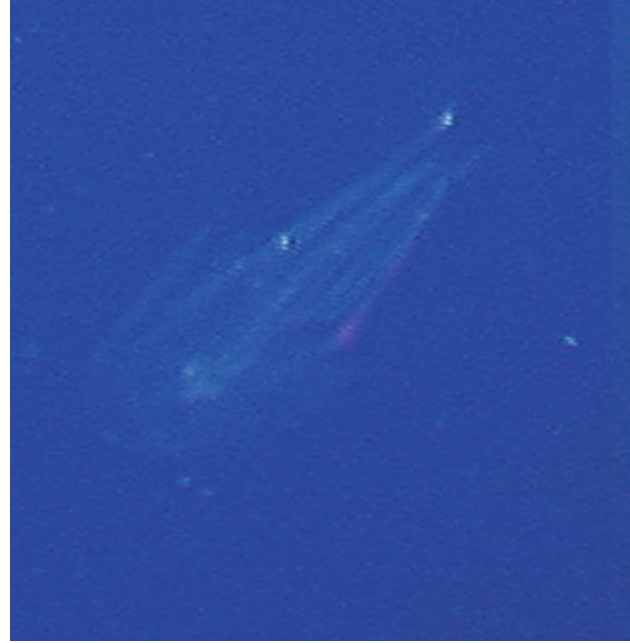

(1)

Fig. 51.8 Eurhamphaea vexilligera in the (a) tentacular and (b) stomodaeal planes, with partially opened lobes, observed at $300 \mathrm{~m}$ depth during ROV HyperDolphin dive 294, and (c) in the stomodaeal plane, with closed lobes, observed at $40 \mathrm{~m}$ depth during the same dive

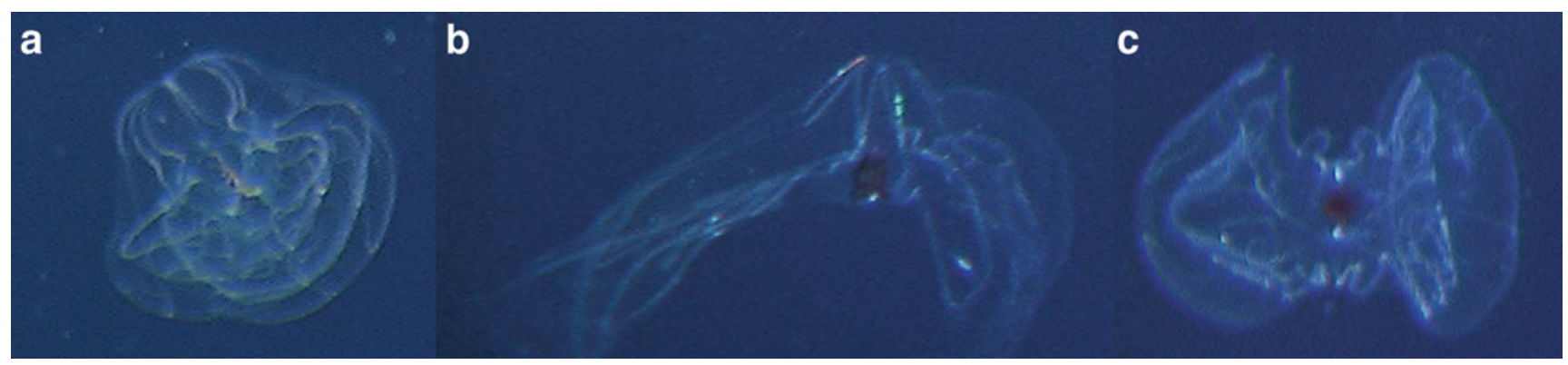

Fig. 51.9 Lampocteis sp. A in the (a) tentacular, and (b) stomodaeal planes, and (c) viewed orally, observed at 1,189 $\mathrm{m}$ depth during ROV HyperDolphin dive 294

Genus Eurhamphaea Gegenbaur, 1856

Eurhamphaea vexilligera Gegenbaur, 1856 (Fig. 51.8)

Body with a pair of muscular, bowl-like lobes at oral end, body surface smooth, highly compressed in tentacular plane; auriculo-tentacular sides extended into two subconical processes at aboral end, each with a long filamentous "tail", subtentacular comb rows extending to tips of these aboral processes; substomodaeal comb rows reaching level of bases of aboral processes; small red vesicles, also present in its cydippid larva, interspersed between ctenes of comb rows, extending onto oral lobes along the substomodaeal meridional canals; with four short, broad, ciliated auricles; with small, inconspicuous, unsheathed tentacles, with tentilla, between the lobes; four interradial canals arising from infundibulum, branching into eight adradial canals; substomodaeal adradial canal supplying substomodaeal meridional canal at aboral end of substomodaeal comb row; subtentacular adradial canal supplying subtentacular meridional canal partway along subtentacular comb row slightly aboral of level of deeply sunken statocyst; paragastric canal present.

Comments: vesicles release reddish-brown, luminescent ink when disturbed. Only observed shallower than $300 \mathrm{~m}$ depth during the present study.

Family Lampoctenidae Harbison, Matsumoto and Robison, 2001

Genus Lampocteis Harbison, Matsumoto and Robison, 2001

\section{Lampocteis sp. A (Fig. 51.9)}

Body with a pair of bowl-like lobes at oral end, body surface smooth, slightly compressed in tentacular plane; without deep notch at level of infundibulum between adjacent subtentacular comb rows?; with four short, wide, ciliated auricles, arising from subtentacular comb rows at level of aboral end of stomodaeum; stomodaeum large, strongly pigmented; with small, inconspicuous, unsheathed tentacles between lobes at level of mouth; paragastric canals large, with blindly-ending diverticula; four interradial canals 


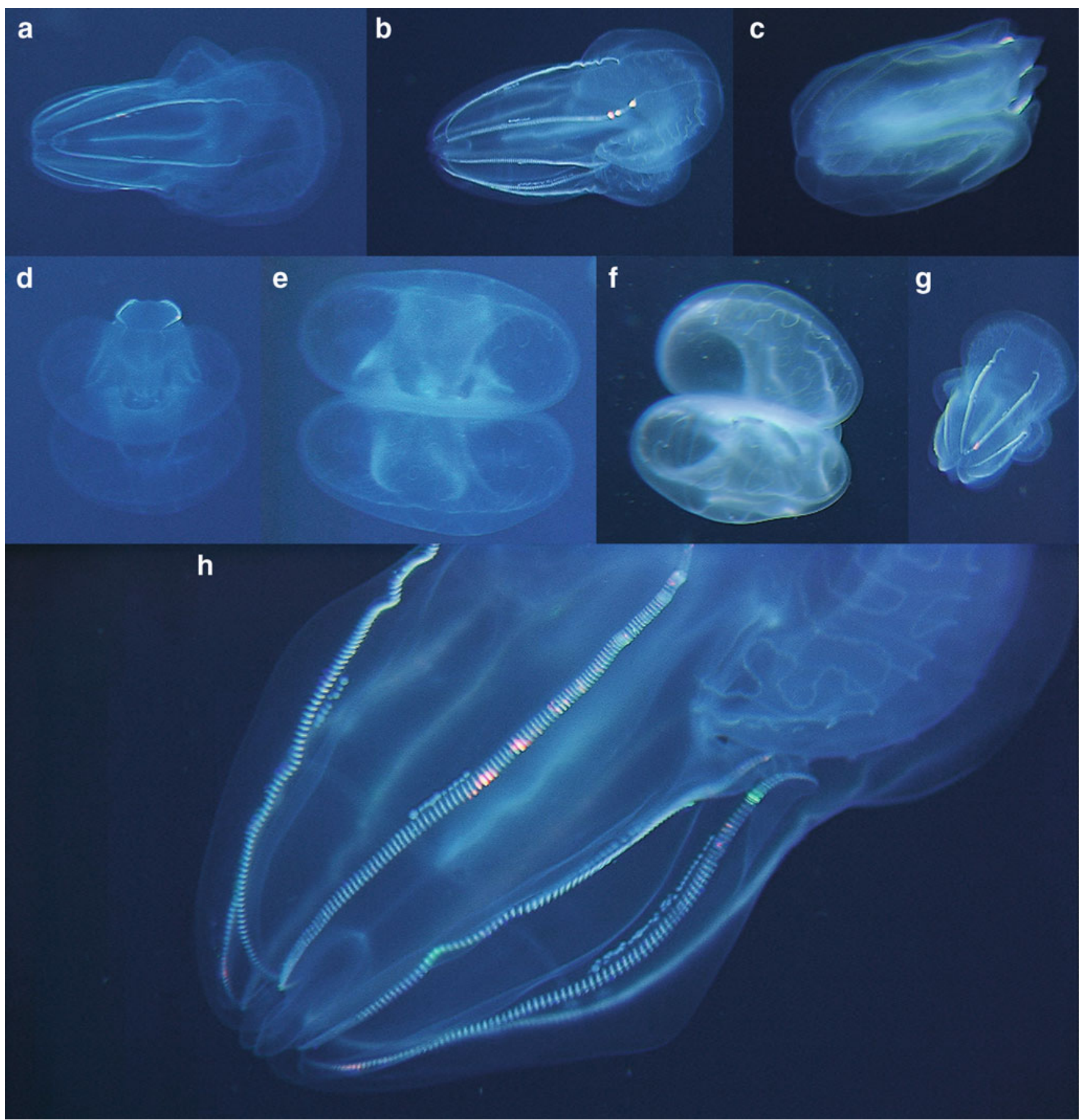

Fig. 51.10 Lobata sp. A in the (a) tentacular, (b) quasi-tentacular, (c) oral-stomodaeal, (d) oral-tentacular, (e) and (f) oral, and (g) aboraltentacular planes, with a close-up of the aboral region (h) showing the

arising from funnel and supplying the adradial canals; meridional canals end blindly aborally.

Comments: Apart from the absence of the deep notch at the level of the infundibulum, this species fits perfectly the generic diagnosis of Lampocteis. The present authors believe that the diagnosis for the genus Lampocteis should be emended by the deletion of this character. The present configuration of the adradial canals supplying the meridional canals and auricular stubs. The figured animal was observed at 1,240 $\mathrm{m}$ depth during ROV HyperDolphin dive 294

species seems much softer in consistency than its congener Lampocteis cruentiventer Harbison, Matsumoto and Robison, 2001, and is similarly unable to swim using its oral lobes.

Family incertae sedis

Lobata sp. A (Fig. 51.10) 


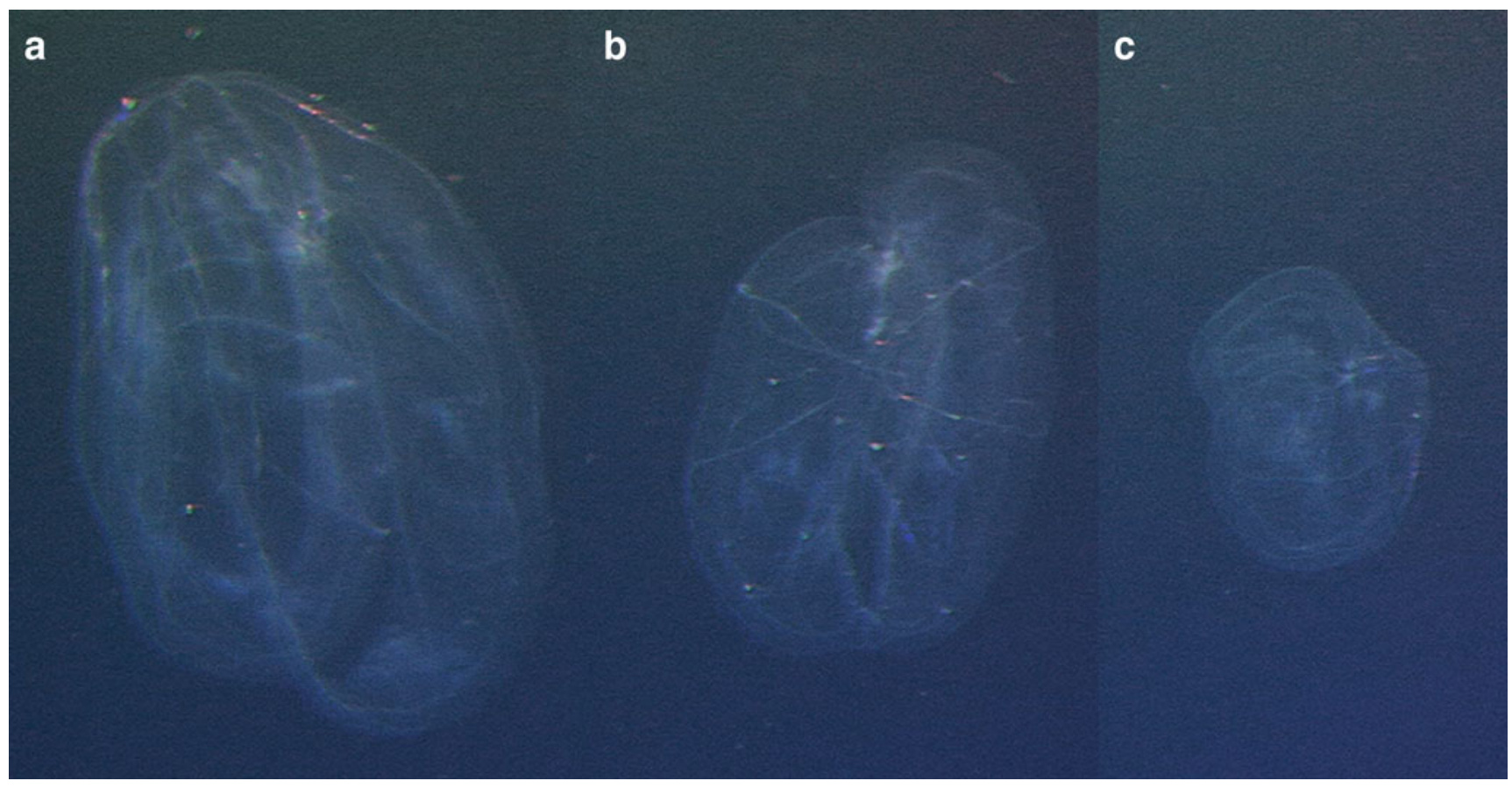

Fig. 51.11 Thalassocalyce sp. A in the (a) quasi-tentacular, (b) aboral, and (c) in its medusoid configuration in the quasi-tentacular plane. The figured animal was observed at $895 \mathrm{~m}$ depth during ROV HyperDolphin dive 226

Body with a pair of muscular, bowl-like lobes at oral end, body surface smooth, slightly compressed in tentacular plane; gelatinous ridges between adjacent comb rows, becoming more pronounced towards aboral end; deeply sunken statocyst, approximately at midpoint between top of stomodaeum and aboral end of gelatinous ridges; without auricles, instead subtentacular comb rows end on stubby protrusions near mouth; with small, inconspicuous tentacle bulbs between the lobes flanking the mouth; stomodaeum long, two-thirds length of substomodaeal comb rows, transparent; infundibular canal short; four interradial canals arising from funnel and supplying the adradial canals; meridional canals end blindly aborally.

Comments: The configuration of the adradial canals supplying the meridional canals partway along their length is the same canal structure as that observed in the Lampoctenidae Harbison et al., 2001, and Lobatolampeidae Horita, 2000. The lack of auricles and the transparent stomodaeum both serve to distinguish it from the Lampoctenidae, while the well-developed lobes, lack of cilia near the distal ends of the subtentacular comb rows, and the substomodaeal comb rows not ending blindly, all serve to distinguish it from the Lobatolampeidae. It seems as if a new family and genus will have to be erected to contain the present species. As in the Lampoctenidae, the lobes are often pursed together when feeding.

Order Thalassocalycida Madin and Harbison, 1978

Family Thalassocalycidae Madin and Harbison, 1978

\section{Genus Thalassocalyce Madin and Harbison, 1978}

Thalassocalyce sp. A (Fig. 51.11)

Body medusa-like, slightly oval in cross-section with longer axis in tentacular plane, with central conical peduncle bearing gut, mouth and tentacles, lobes and auricles absent; comb rows short; tentacle bulbs situated on sides of central peduncle, halfway down stomodaeum, tentacles with tentilla, without tentacle sheaths; gut wide, flat; mouth slit-like, in stomodaeal plane; medusoid body covered with extensively looping canals arising from meridional canals.

Thalassocalyce inconstans Madin and Harbison, 1978 also has the following feautures: comb rows $25-33 \%$ of total oral-aboral distance, all equal length, around 23 ctene plates each. Statocyst slightly sunken below aboral surface; pole plate extends about halfway to comb rows in stomodaeal plane; paragastric canals run down along flat sides of stomodaeum, turn outward and end blindly at level of mouth. Gut somewhat constricted in center, with upper half expanded into digestive region. Funnel canal broad, extending from digestive region to statocyst. Meridional canals running beneath comb rows end blindly aborally. Two perradial canals arise from gut in tentacular plane, thereafter branching into interradial canals; a tentacular canal branches from one of the two interradial canals in each half of the animal and descends to supply tentacle bulbs; each interradial canal branches into two adradial canals, one adradial canal supplies the substomodaeal 


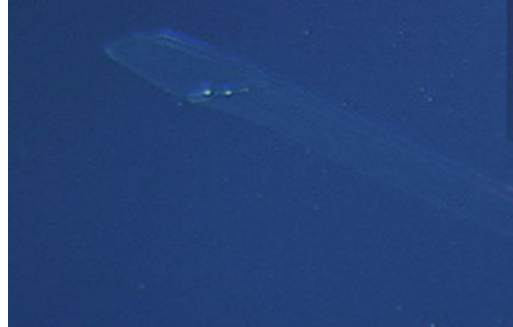

Fig. 51.12 Cestum veneris in the (a) quasi-tentacular plane, and (b) oral view. The figured animal was observed at $299 \mathrm{~m}$ depth during ROV HyperDolphin dive 294

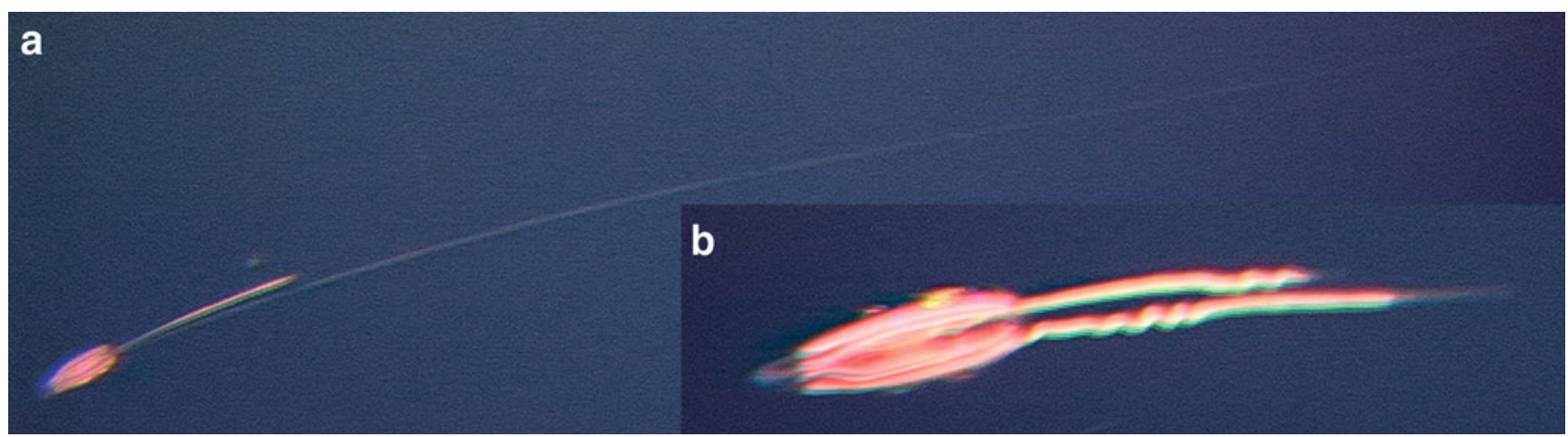

Fig. 51.13 Cydippida sp. A with (a) tentacles extended, and (b) tentacles partially retracted. The figured animal was observed at $856 \mathrm{~m}$ depth during ROV HyperDolphin dive 226

meridional canal directly at the oralmost end of the comb row, the other adradial canal (subtentacular) branches off a long, looping canal that runs along the periphery of the belllike body for one quarter of its circumference before looping back to supply oral end of substomodaeal comb rows at the junction with the other adradial canal; subtentacular adradial canals run straight down to edge of bell before looping back to supply subtentacular comb rows at their oralmost ends; subtentacular canals contain numerous large spherical ova in their descending limbs.

Comments: The form observed at the Hatoma Knoll vent site seemed to be much larger than the maximum size of $15 \mathrm{~cm}$ in diameter reported for T. inconstans (Madin and Harbison 1978b). Gonads were developed and easily visible in the video record. Although several individuals of $T$. inconstans described by Madin and Harbison (1978b) also had developed gonads at a diameter of only $5 \mathrm{~cm}$, it is possible that the form we observed was just a vastly more mature and developed stage of this species. It is also possible that it could be a larger, undescribed species, so we have refrained from giving a specific epithet for the animals we observed at the Hatoma Knoll until pristine specimens can be sampled, morphological comparisons made, and a molecular analysis undertaken.
Order Cestida Gegenbaur, 1856

Family Cestidae Gegenbaur, 1856

Genus Cestum Gegenbaur, 1856

Cestum veneris Lesueur, 1813 (Fig. 51.12)

Body elongate, flattened in tentacular axis, to $1.5 \mathrm{~m}$ length, usually $<0.8 \mathrm{~m}$; with tentacles arising from deep sheaths, extending along entire oral margin of body, with fine tentilla; substomodaeal comb rows greatly elongated; subtentacular comb rows rudimentary; no lobes or auricles; four interradial canals arising from funnel and supplying adradial canals, subtentacular meridional canals curving upward/orally after supplying the rudimentary comb rows then curve outwards, running along midline of animal to its extreme ends and joining the substomodaeal meridional canals and oral forks of the paragastric canals; gonads continuous under substomodaeal meridional canals.

Comments: body often with yellow or brown pigment spots; escapes by graceful rapid undulating of the body; has a mertensid-like "cydippid" larval stage.

Order Cydippida Lesson, 1843

Family incertae sedis

Cydippida sp. A (Fig. 51.13)

Body elongate, teardrop-shaped with rounded aboral end, compressed slightly in tentacular plane, with grooves 


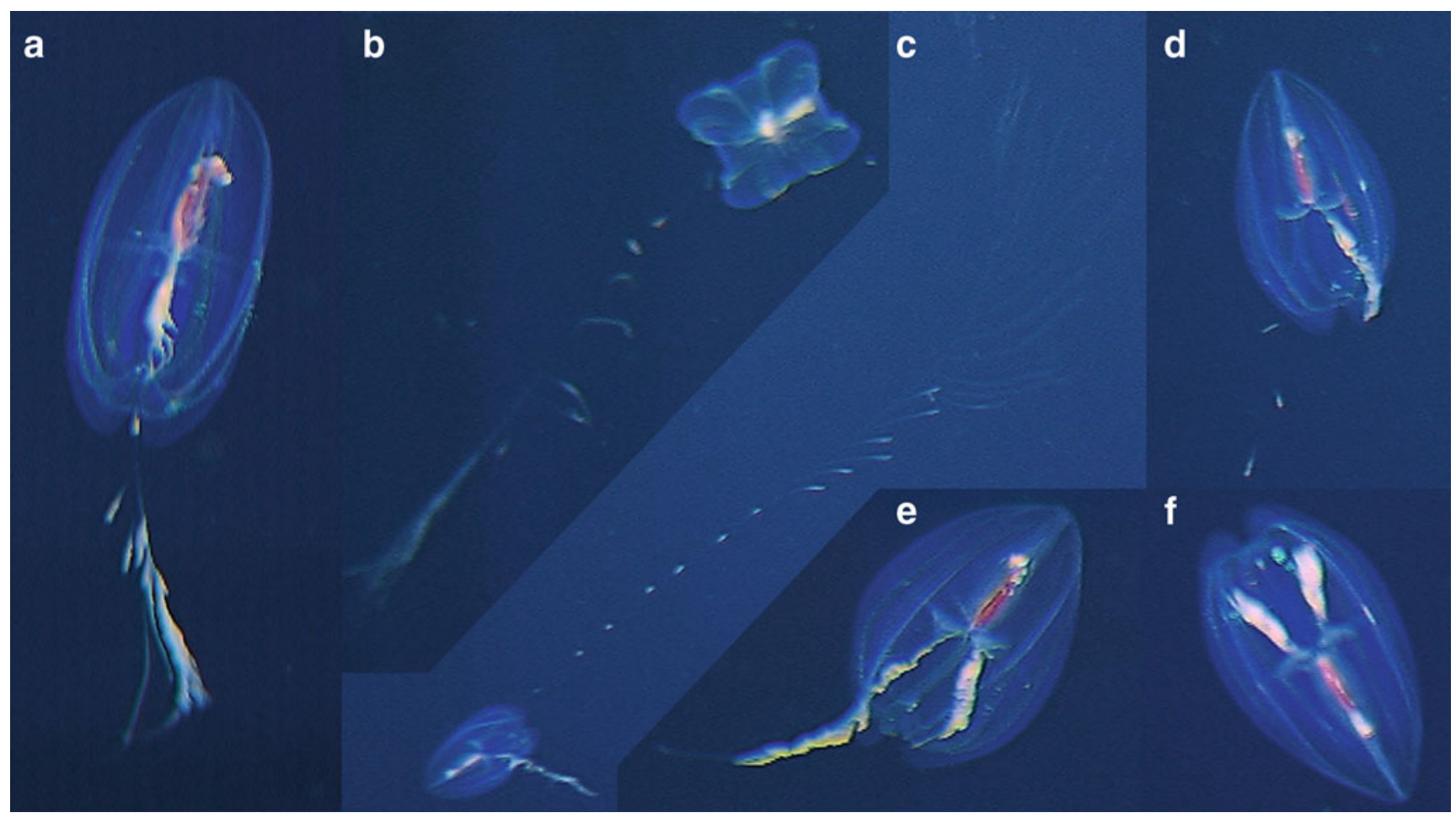

Fig. 51.14 Cydippida sp. B in the (a) stomodaeal plane, (b) viewed aborally, (c) with tentacles extended, (d) with one tentacle retracted, (e) with both tentacles almost retracted, and (f) in the tentacular plane. The figured animal was observed at $534 \mathrm{~m}$ depth during ROV HyperDolphin dive 294 between comb rows; oral end with four horns/keels, each extending out from between subtentacular and substomodaeal comb rows; comb rows of similar lengths, extending to around two-thirds of body length; meridional canals sink into the mesoglea at oral ends of comb rows and extend to bases of oral horns; stomodaeum large, $70 \%$ of body length; tentacles with tentilla, yellowish, in sheaths, exiting from mid-point of body within deep grooves that extend from the oral to aboral ends of the comb rows; tentacle bulbs parallel, lying close to stomodaeum and extending past its aboral end and the aboral end of the infundibulum, two-fifths to four-ninths of body length, yellow-orange in colour.

Comments: A species resembling the present species has been referred to in several publications as "Ctenoceros" (e.g. Johnsen 2005; Lindsay and Hunt 2005). Individuals observed at the Hatoma Knoll all had orange coloration to the body and meridional canals. Usually they were observed with one tentacle fully extended and the other partially retracted. A new family will need to be erected to contain this undescribed genus and species.

Cydippida B (Fig. 51.14)

Body teardrop-shaped, aboral end with four keels between subtentacular and substomodaeal comb rows, body square in cross-section, with wide grooves between subtentacular comb rows, ridges between subtentacular and substomodaeal comb rows, oral end conical, bluntly tapering; comb rows of similar lengths, covering almost entire body, extending/bending orally over aboral end towards statocyst; stomodaeum large, $50 \%$ of body length; tentacles with filamentous tentillae, whitish, in sheaths exiting from aboral end of body; tentacle bulbs boomerang-shaped, at midpoint of body, flanking infundibulum, perpendicular to oral-aboral axis, one fourth body width in length, whitish.

Comments: Without information on the branching pattern of the interradial and adradial canals it is impossible to tell to which group of the polyphyletic "Cydippida" this species belongs. Tentacle bulbs angled parallel to the oral-aboral axis do not exist in any of the currently described species and we have therefore treated it here as a new genus and species. The stomodaeum may be pigmented along at least half of its length but the video resolution was not high enough to determine if the colour was from an ingested prey item or in the walls of the stomodaeum itself. This species closely resembles the animal on the back cover of Kovacs and Madin (1996).

Phylum Cnidaria

Order Siphonophorae Eschscholtz, 1829

Suborder Physonectae Haeckel, 1888

Family Pyrostephidae Moser, 1925 
Fig. 51.15 Bargmannia

elongata captured at $468 \mathrm{~m}$ depth during ROV HyperDolphin dive 296

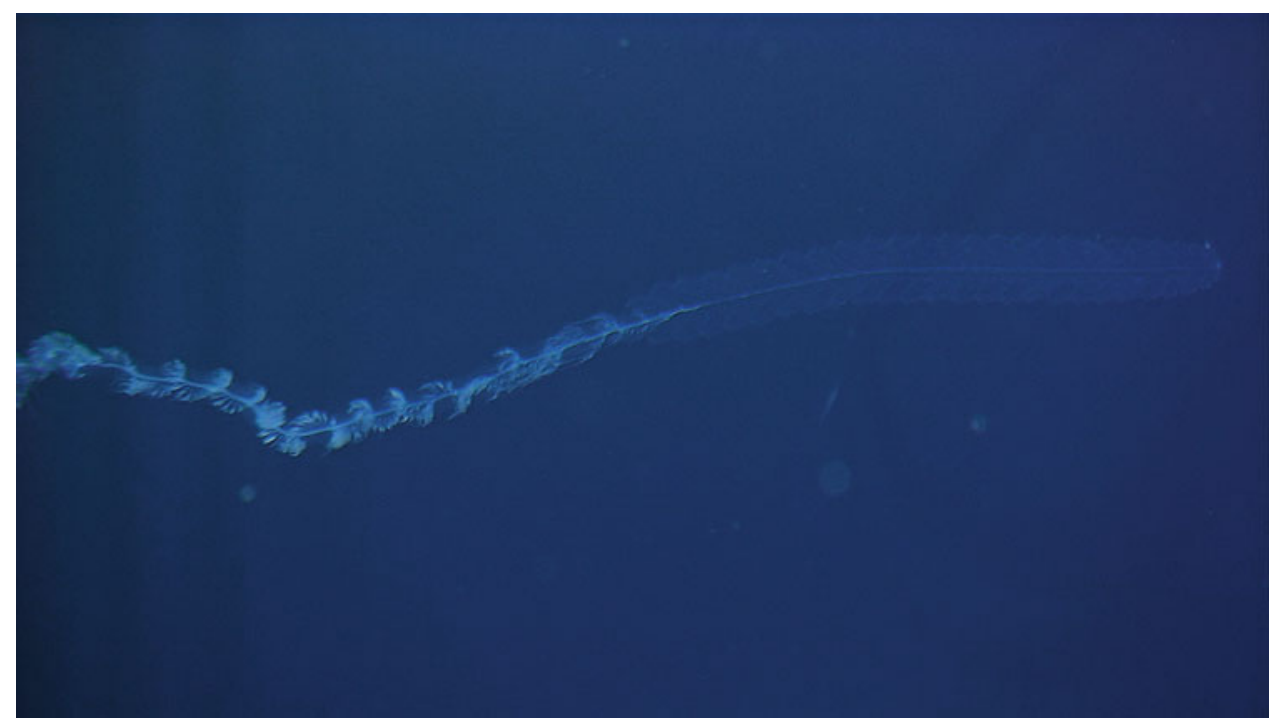

Genus Bargmannia Totton, 1954

Bargmannia elongata Totton, 1954 (Fig. 51.15)

Pneumatophore: without apical pore.

Nectosome: easily up to 20 pairs of nectophores, insterted on the dorsal side of the stem. Nectophores elongate with a large, triangular thrustblock and mesogleal plug, axial wings vestigial. Nectophore with upper-lateral, lower-lateral, and vertical lateral (meso-lateral) ridges, but no lateral ridge. Upper-lateral ridge extending distally over upper surface of nectophore, passing first diagonally towards upper midline, giving off short ridge, turning abruptly outwards, and then subdividing into inner and outer upper-lateral ridges at 3/10 nectophore length (from ostium); short ridge passing downwards towards upper midline. Outer upper-lateral ridge reaching ostium and without extra branch directed proximally. Mouthplate divided. Nectosac basically cylindrical, with hemispherical muscle-free zone on proximal part. Lateral radial canals straight, arising from the upper radial canal and not forming a junction with the pedicular canal. Upper and lower radial canals straight. Descending branch of pedicular canal absent.

Siphosome: diffuse, with siphosomal tentacles. Devoid of fully-formed dactylozooids. Colonies single-sexed (dioecious). Each cormidium with simple tentacle-like structure attached to stem midway between successive gastrozooids; with single gonodendron; with four bud-like structures (? vestigial dactylozooids) with sexually dimorphic arrangement. Second tentacle and fifth bud occasionally present proximal to a gastrozooid. The full zooid complement of one cormidium comprises one gastrozooid, one siphosomal tentacle (as tentaculozooid), one gonodendron (as gonozooid, either male or female), two gastrozooidassociated bracts, two left lateral bracts, and two right lateral bracts. Tentilla without basal involucrum, straight to slightly twisted cnidoband with large nematocysts, probably stenoteles, and two types of smaller nematocysts, single long terminal filament. Bracts delicate and foliaceous, rounded distally, with patches of ectodermal cells on the upper surface, especially distally, with no semicircular ridge, with or without pair of lateral cusps at midbract.

Comments: An entire individual (HD296SS2), that figured, was captured at $468 \mathrm{~m}$ depth during ROV HyperDolphin dive 296.

Type Material: Holotype collected in shallow waters at Discovery II station $699\left(14.45^{\circ} \mathrm{N} 30.04^{\circ} \mathrm{W}, 0-370 \mathrm{~m}\right)$, west of the Cape Verde islands, in tropical waters. Brit. Mus. (Nat. Hist.) Register No. 1952. 11. 19. 7-25.

Family Forskaliidae Haeckel, 1888

Genus Forskalia Kölliker, 1853

Forskalia formosa Keferstein and Ehlers, 1860 (Fig. 51.16)

Nectophores flattened in lateral plane, with large, pointed left axial wing; and shallow, but broad and rounded right wing. Small apical incision between them. Small lateral, but no baso-lateral pockets. No rete mirabile. No sulphur-yellow pigment spot on upper side of ostium of the nectophore. Nectosac extends to just over $40 \%$ nectophore length, radial canals straight. Gastrozooids borne on long peduncles covered with bracts. Four types of adult bract (stem, bolster and two types of knee-shaped); knee-shaped ones without side branch to canal. Gonodendra with female gonophores, in two bunches, attached close to bases of palpacle-bearing gonopalpons; male gonophores borne on long stalk.

Comments: Colonies rotate while swimming. Cylindrical nectosome tapers apically and is narrower than siphosome, which is about three times longer than nectosome in mature, undamaged specimens and also tapered. Pneumatophore not nested within nectophores, clearly extended. Siphosomal stem spiralled, with gastrozooids arranged in four rows. Stomach bases and cnidobands of tentilla orange-red. 
Fig. 51.16 Forskalia formosa individual observed at $241 \mathrm{~m}$ depth during ROV HyperDolphin dive 294

Fig. 51.17 Marrus orthocanna individual captured at $1,330 \mathrm{~m}$ depth during ROV HyperDolphin dive 226
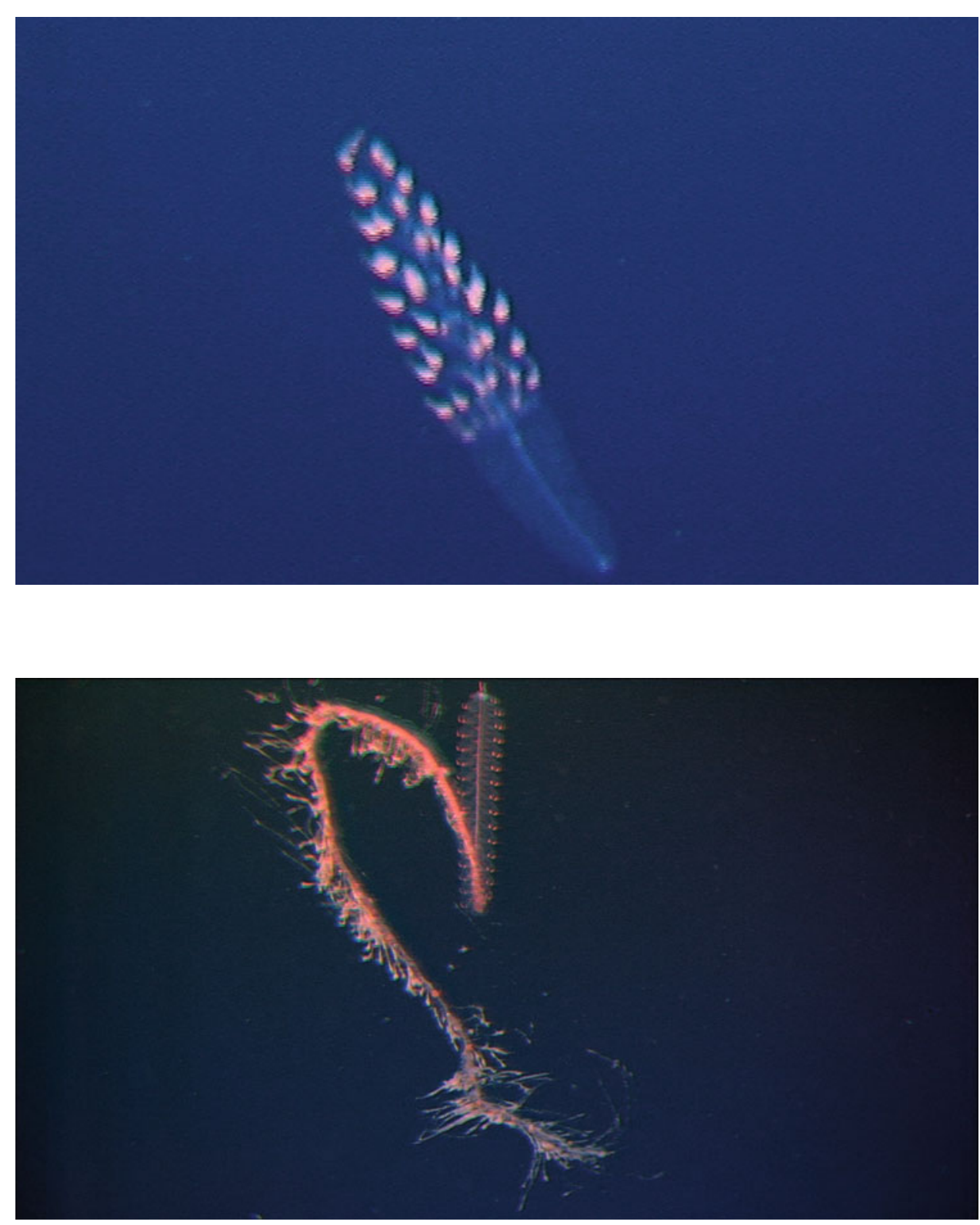

Type Material: Holotype collected from Messina in the Mediterranean Sea in winter 1859-1860 (38.1833N; 15.55E). Paratype collected during Johnson Sea-Link I dive 2943 (position: 35.76N, 3.225W, depth: $590 \mathrm{~m}$, date: 14 April 1991), curated at Natural History Museum, London (reg. no. BMNH 2001.6916).

Family incertae sedis

Marrus orthocanna (Kramp, 1942) (Fig. 51.17)

Nectosome: Nectophores inserted on the dorsal side of the stem, each up to $15 \mathrm{~mm}$ high, with a lateral furrow at one-third the nectophore height, with truncate axial wings, broad thrust block and large mesogloeal plug. Upper-lateral ridges bifurcate distally, with bifurcation of nectophoral upper-lateral ridges at same level or proximal to the lateral furrow. No vertical-lateral or lateral ridges. Nectosac with a proximal muscle-free zone. All radial canals of nectosac straight and pigmented deep orange-scarlet. Descending branch of pallial canal absent.

Siphosome: stem pigmented deep orange-scarlet. Distal facet of bracts divided, with median ridge covered in line of nematocysts, bracteal canal divides at distal end into two longitudinal branches that are also overlain with nematocysts. Unicornuate tentacles with no involucrum and straight to loosely-coiled cnidoband. With both male and female gonophores (monoecious), with female gonophores containing a single egg. No palpons on gonodendra or anywhere else.

Comments: An entire individual (HD226GS1) was captured at 1,330 m depth during ROV HyperDolphin dive 226.

Type Material: Holotype caught in Baffin Bay $(67.7 \mathrm{~N}$ 60.517W) at Godthaab Station 162b in 1928.

Marrus sp. A (Fig. 51.18) 
Fig. 51.18 Marrus sp. A individual captured at $668 \mathrm{~m}$ depth during ROV HyperDolphin dive 296

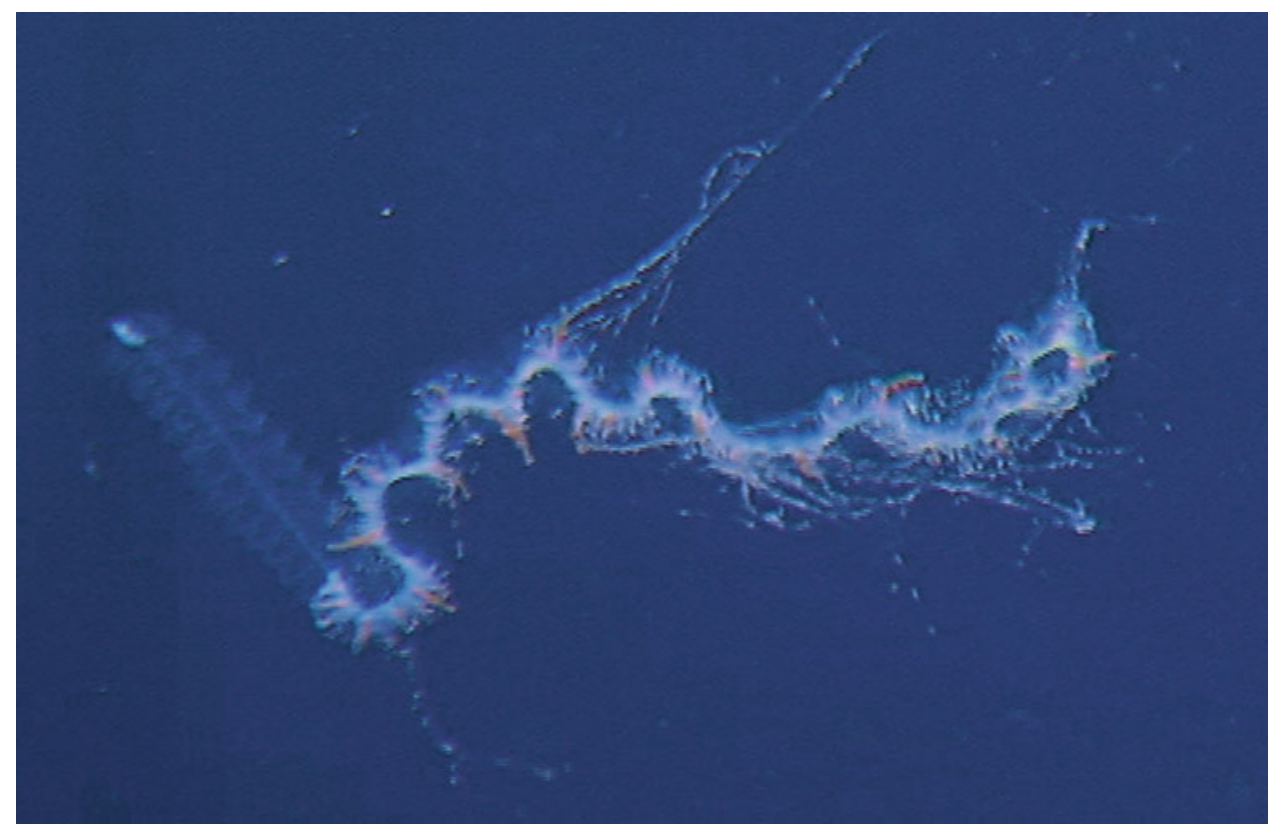

Nectosome: Nectophores inserted on the dorsal side of the stem; nectosac with a proximal muscle-free zone; radial canals of nectosac all straight. Descending pallial canal absent.

Siphosome: stem white, gastrozooids orange with white mouths; bracts of Marrus-type.

Comments: An individual (HD296SS5) was captured at 668 m depth during ROV HyperDolphin dive 296, but the specimen was too damaged to determine more than that it was an undescribed species assignable to the genus Marrus as it is now defined.

Suborder Calycophorae Leuckart, 1854

Family Prayidae Kölliker, 1853

Subfamily Prayinae Chun, 1897

Genus Rosacea Quoy and Gaimard, 1827

Rosacea plicata Bigelow, 1911 (Fig. 51.19)

Polygastric stage - two nectophores. N1 nectophore: up to $24 \mathrm{~mm}$ high, rounded and oblong, hydroecium elongate, deep, with a lower sill, ascending surface diverticulum with no anterior swelling and lying close to hydroecial wall, descending surface diverticulum present, nectosac small, lateral radial canals with complex sigmoid shape. N2 nectophore: up to $29 \mathrm{~mm}$ high, rounded and oblong, resembling N1, but hydroecium shorter and narrower, with a lower sill, and containing the first cormidia.

Sexual stage-Bract: up to $11 \mathrm{~mm}$ wide, smooth, rounded, with three non-apposing lobes (lateral, anterior hydroecial, and posterior hydroecial with a flap on inner surface), six bracteal canals (lateral, anterior and posterior longitudinal canals running parallel to stem, anterior hydroecial, posterior hydroecial, upper) without terminal swellings but with blind branches, anterior hydroecial canal approximately twice length of posterior hydroecial canal, central organ positioned at base of lateral bracteal canal, upper bracteal canal branching from posterior hydroecial canal, distal to posterior longitudinal canal, and reaching upper bracteal margin. Gonophore: with prominent apico-lateral keel, two asymmetric mantle canals, nectosac two-thirds of gonophore height with rounded apex, radial canals straight.

Comments: An individual (2K1183GS1) was sampled at $675 \mathrm{~m}$ depth during Shinkai 2000 dive 1183.

Type Material: Lectotype collected from Bay of Biscay (47.05N, 7.917W) by the H.M.S. Research on 25 July 1900 and kept at the Natural History Museum, London, under registration number BMNH1939.6.10.1.

Family Clausophyidae Totton, 1965

Subfamily Kephyinae Mapstone, 2009

Genus Kephyes Pugh, 2006 (Fig. 51.20)

Kephyes sp. (spp.?)

Kephyes ovata (Keferstein and Ehlers, 1860).

Polygastric stage: Calycophoran siphonophore with two dissimilar nectophores, with anterior nectophore partially apposed to and partially linearly adjoined to elongate posterior one, nectophores lacking ridges, cusps and mouthplates, laterally compressed, with rounded apices, with somatocysts in both nectophores, somatocyst extending to apex of anterior nectophore; hydroecium in anterior nectophore extensive, greater than $70 \%$ of nectophore height, without median mesogloeal protuberance; nectosac extends to greater than $85 \%$ height of nectophores, looped to slightly looped lateral radial canals, origin of lateral radial canals variable, often arising separately from upper canal, pedicular canal with long descending branch in both nectophores. 


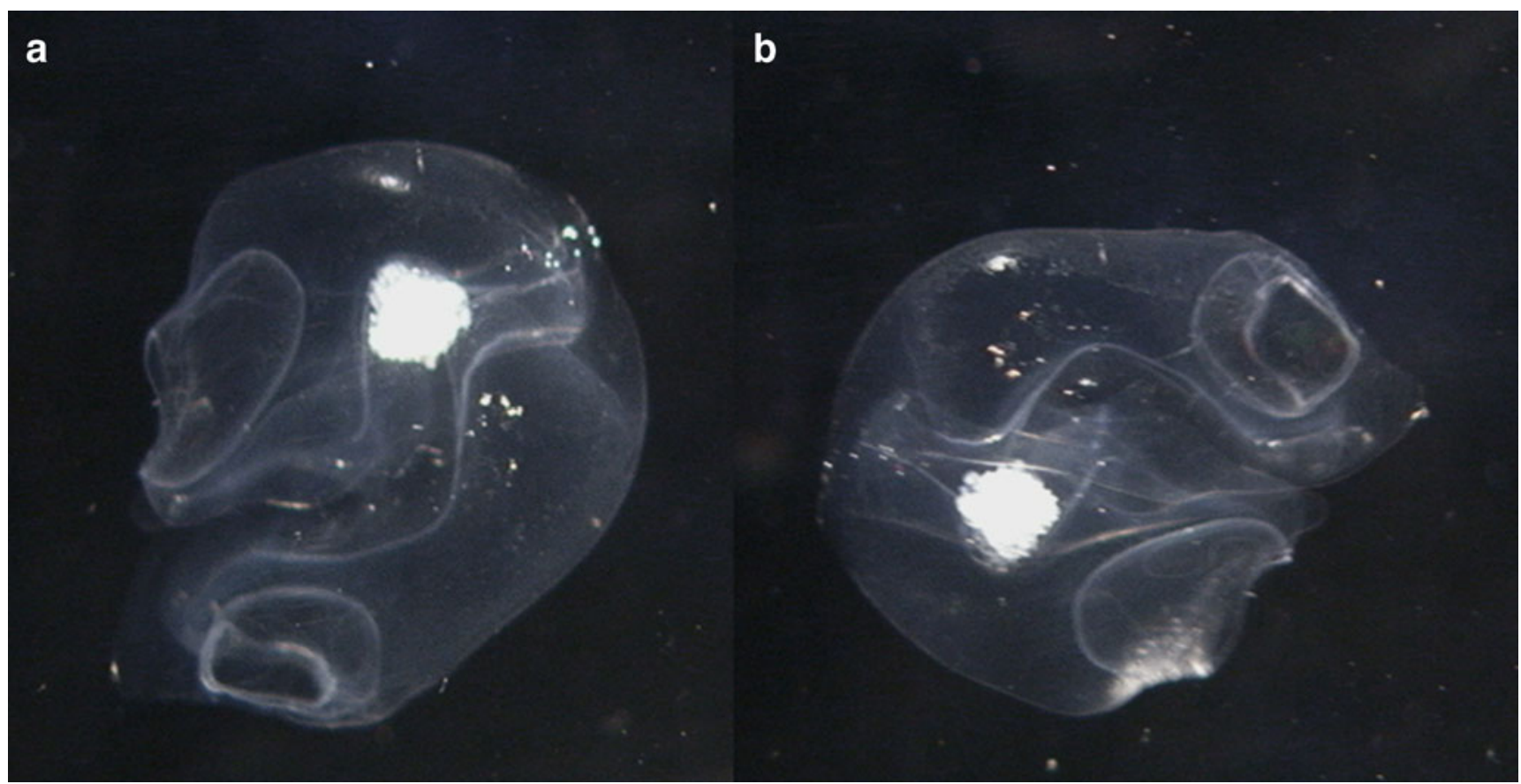

Fig. 51.19 Rosacea plicata captured at $675 \mathrm{~m}$ depth during Shinkai 2000 dive 1183 (a, b)

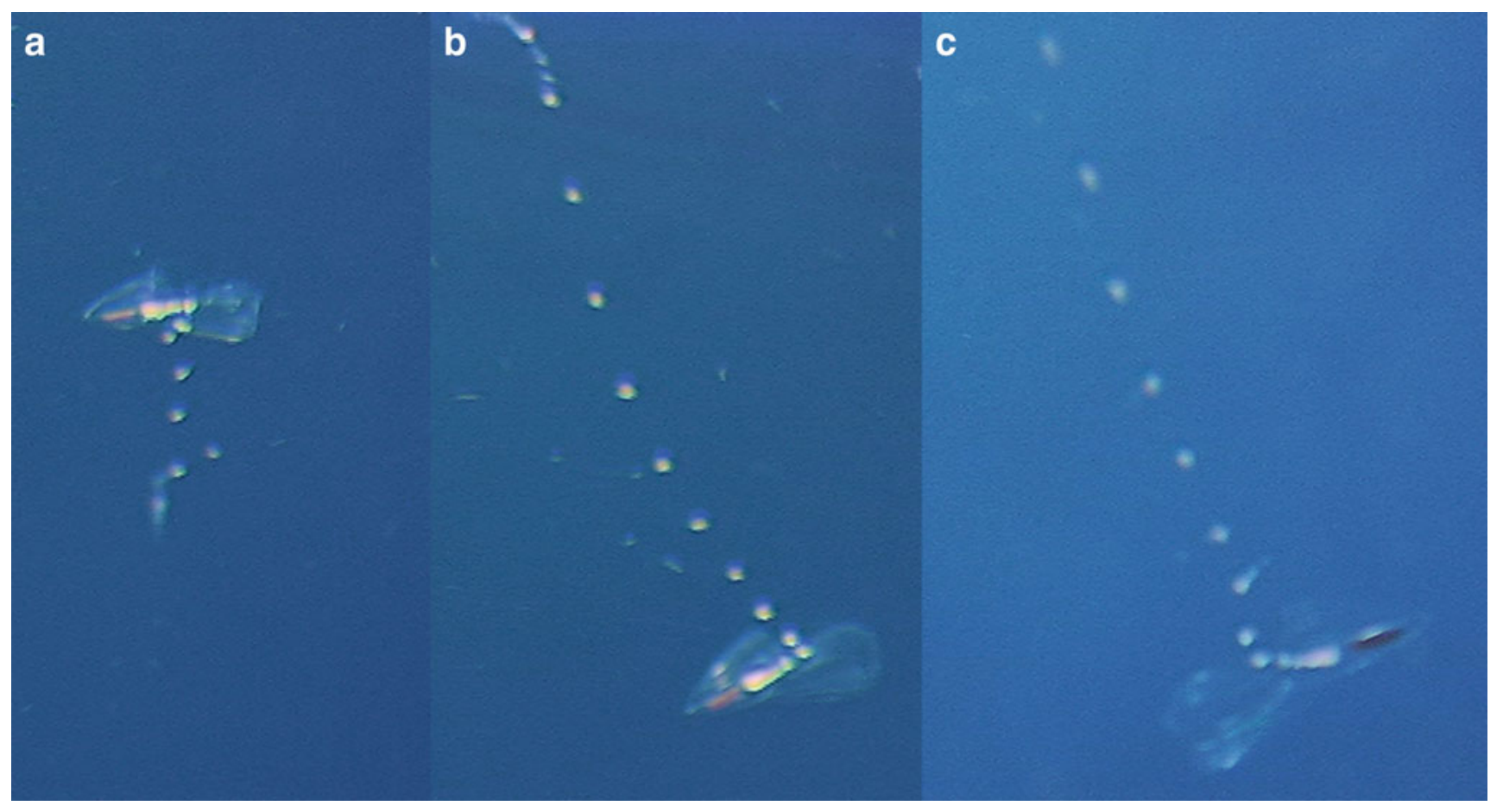

Fig. 51.20 Kephyes sp. observed at 1,420 m depth during ROV HyperDolphin dive 296 (a, b, c) 


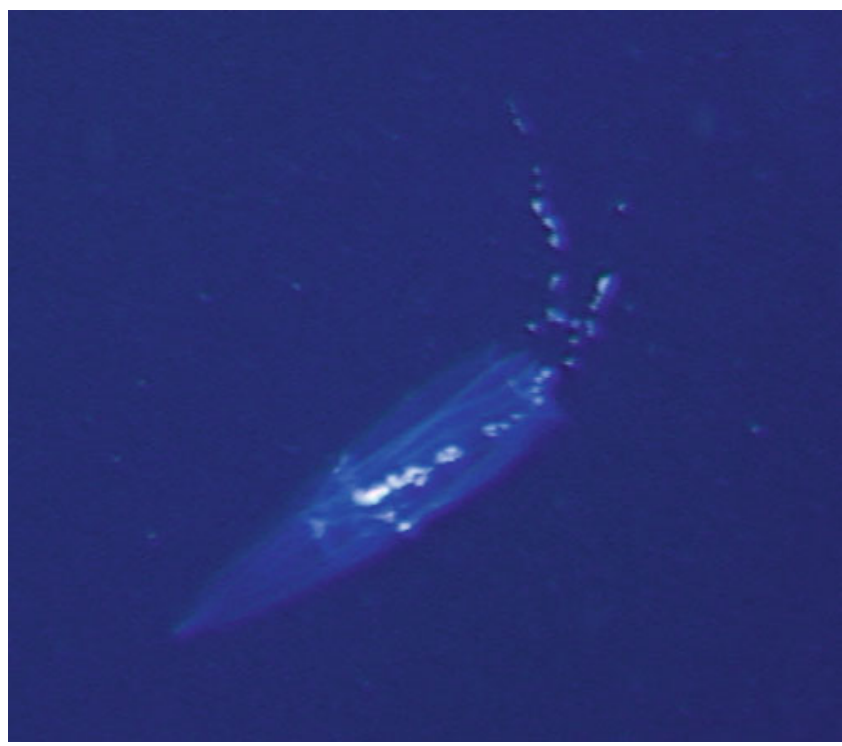

Fig. 51.21 Chuniphyes multidentata observed at 1,193 m depth during ROV HyperDolphin dive 67

Eudoxid stage: bract headpiece short, with rounded proximal end, bracteal canal system constituted by phyllocyst that almost reaches proximal end of headpiece, two hydroecial canals extending down extensive neck shield, and moderately long longitudinal canal, extending as spurs beyond the origins of the hydroecials; gonophore without distinctive ridges, with large nectosac, with flap on posterior end of right hydroecial wing, pedicular canal divides apically to form two mantle canals.

Comments: At least two species referable to this genus have been identified (personal observation). The quality of the video during the present surveys did not allow accurate identification to species level. Animals identifiable to this genus were observed at 1,078 and 1,096 $\mathrm{m}$ depth during ROV HyperDolphin dive 67, and 1,420 m during ROV HyperDolphin dive 296.

Type Material: Holotype of generic type (Kephyes ovata) collected from Messina in the Mediterranean Sea in winter 1859-1860 (38.1833N; 15.55E) described under the name Diphyes ovata.

Subfamily Clausophyinae Bigelow, 1913

Genus Chuniphyes Lens and van Riemsdijk, 1908

Chuniphyes multidentata Lens and van Riemsdijk, 1908 (Fig. 51.21)

Polygastric stage:

Anterior nectophore: up to $25 \mathrm{~mm}$ high. Conical nectophore with 4 ridges at apex, each ridge splitting into two in the nectophore's anterior part. Lower lateral ridges joining lower ridges slightly before posterior margin. All ridges forming small teeth at posterior margin. Hydroecium deep, extending to more than half the nectophore's height and with median mesogleal process. Somatocyst with lateral expansions and distinctly demarcated thin anterior branch extending to nectophore apex. Lateral canals sinuous.

Posterior nectophore: up to $34 \mathrm{~mm}$ high. Hydroecial wings well developed, with asymmetric serrated posterior teeth Hydroecial flaps in distal portion of hydroecium. Other ridges with small ostial teeth. Somatocyst thin and elongate, extending to apex of nectophore. Lateral radial canals straight.

Eudoxid stage: indistinguishable from that of Chuniphyes moserae Totton, 1954.

Comments: Ridges a pale gold colour. Animals identifiable to species level were observed at $1,193 \mathrm{~m}$ depth during ROV HyperDolphin dive 67, and 1,364 m during ROV HyperDolphin dive 295.

Type Material: Holotype collected from the Molucca Sea, Philippines, at station 141 (1.01S, 127.42E) of the Siboga expedition on 5 August 1899. Catalogue numbers 44F.I and 44F.J (anterior and posterior nectophores).

Order Anthoathecata Cornelius, 1992

Suborder Filifera Kühn, 1913

Family Bythotiaridae Maas, 1905

Genus Protiaropsis Stechow 1919

Protiaropsis anonyma (Maas, 1905) (Fig. 51.22)

Exumbrella thick, up to $22 \mathrm{~mm}$ high, with deep, rather narrow bell cavity; 4 simple radial canals; no centripetal canals; manubrium barrel-shaped, mouth with four simple lips; "gonads" interradial, on manubrial wall, no transverse folds; $6-12$ hollow marginal tentacles, each terminating in a large cnidocyst cluster, no secondary tentacles; no ocelli.

Comments: The genus Heterotiara is preoccupied and the correct generic designation for this species is Protiaropsis Stechow 1919 (Stechow 1919). Several small individuals have been caught at the Hatoma Knoll (eg. HD294SS4b at $1,416 \mathrm{~m}$ depth, 2K1188SS3C at $990 \mathrm{~m}$ depth) with bell heights 7-9 $\mathrm{mm}$ and with eight tentacles. These were intermediate in morphology with a larger specimen (I050203A$\mathrm{Pa}$ ) with a bell height of $20 \mathrm{~mm}$ and with 8 tentacles, and with Kanaka pelagica Uchida, 1947, the holotype of which is $1.8 \mathrm{~mm}$ in bell height. It seems that $K$. pelagica is a junior synonym of $P$. anonyma (Maas, 1905).

Type Material: two syntypes collected during the Siboga Expedition in a vertical haul $(0-1,000 \mathrm{~m})$ at Station 148 (0.293S, 129.242E) in the Halmahera Sea, Indonesia, on 10 August 1899.

Order Trachymedusae Haeckel, 1866 (1879)

Family Halicreatidae Fewkes, 1886

Genus Halicreas Fewkes, 1882

Halicreas minimum Fewkes, 1882 (Fig. 51.23)

Umbrella thick, disc-like, to $40 \mathrm{~mm}$ diameter, with a small, conical apical projection of mesogloea and eight clusters of gelatinous papillae above bell margin; mouth wide, circular, without distinct lips; without peduncle; without centripetal canals; with eight broad, band-like radial canals and a broad ring canal; gonads flattened, extending 
Fig. 51.22 Protiaropsis anonyma observed at $1,348 \mathrm{~m}$ during ROV HyperDolphin dive 226 in (a) fishing/feeding position, (b, c, d) during escape, and (e) a second individual (height $7 \mathrm{~mm}$ ) captured at $990 \mathrm{~m}$ depth during Shinkai 2000 dive 1188
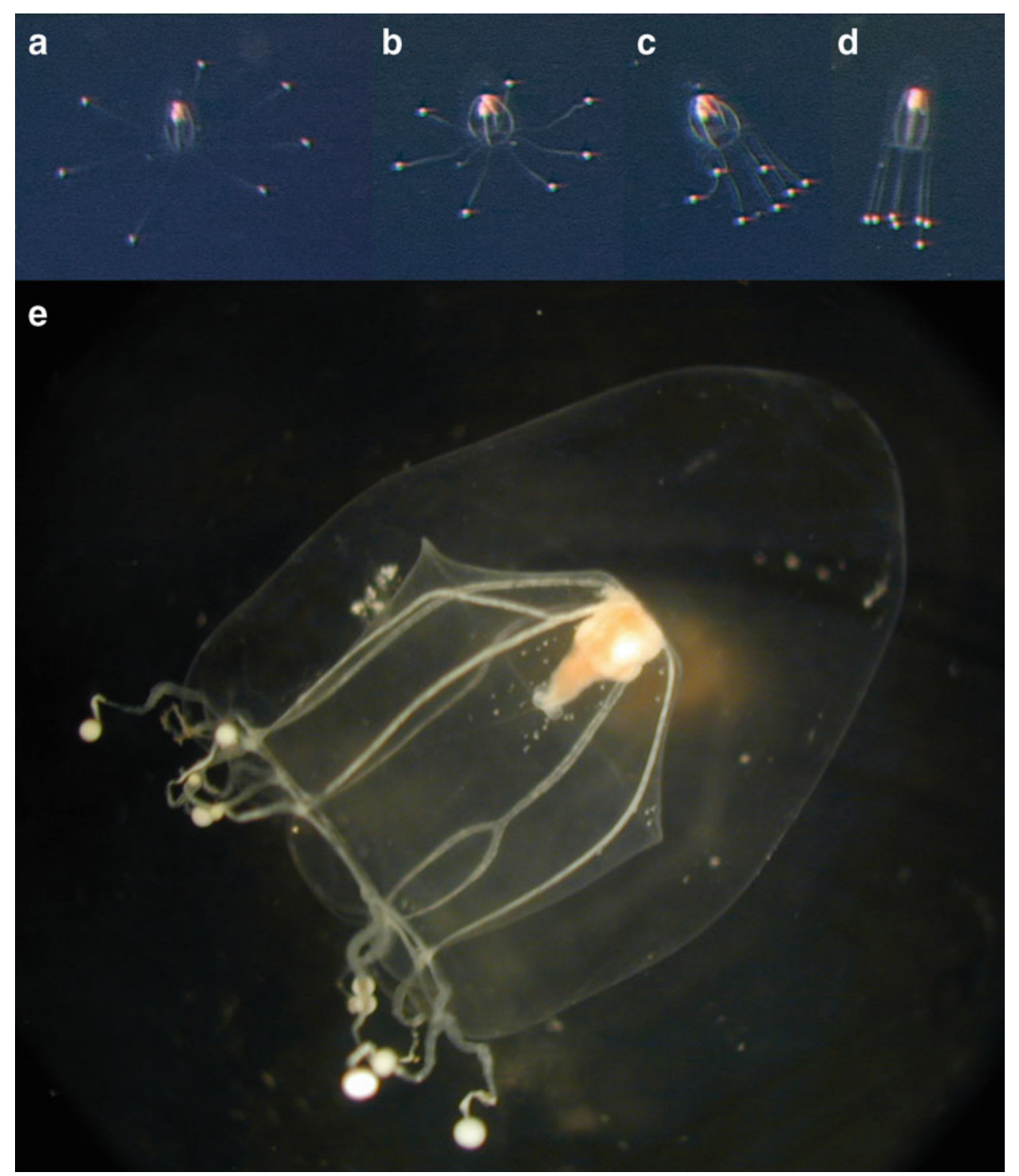

along almost entire length of canals; with up to 640 marginal tentacles of different sizes, all structurally alike and arranged in a single series; each marginal tentacle with flexible proximal portion and stiff spine-like distal portion; with 3-4 free ecto-endodermal statocysts per octant.

Comments: An individual was observed at $721 \mathrm{~m}$ during ROV HyperDolphin dive 294.

Type Material: Holotype collected off the New England Coast.

Genus Haliscera Vanhöffen, 1902

Haliscera bigelowi Kramp, 1947 (Fig. 51.24)

Umbrella 15-19 mm wide, 9-10 $\mathrm{mm}$ high, almost hemispherical, umbrella with a very thick dome-shaped mesogleal apex comprising about $2 / 3$ of the umbrella height, mesoglea thin at sides and margin; velum very broad; manubrium broad, flat, slightly conical; mouth simple, circular; eight straight, broad radial canals and broad circular canal; in adults, about 12 solid marginal tentacles in each octant, flexible proximally, stiff distally; the base of each tentacle surrounded by a small thickening of marginal cnidocyst tissue; with eight gonads broadly oval, flat, about $2 / 5$ as long as the radial canals, situated slightly nearer the manubrium than to bell margin; three statocysts in each octant.

Comments: One small individual (2K1188SS2) was caught at the Hatoma Knoll during Shinkai 2000 dive 1188 at $833 \mathrm{~m}$ depth.

Type Material: Holotype collected in the Northern Atlantic.

Family Rhopalonematidae Russell, 1953

Genus Pantachogon Maas, 1893

Pantachogon haeckeli Maas, 1893 (Fig. 51.25)

Exumbrella to about $15 \mathrm{~mm}$ high, sometimes slightly higher than wide, bell-shaped, with thin jelly and without apical thickening or an apical projection when mature; 
Fig. 51.23 Halicreas minimum

(a) captured at $770 \mathrm{~m}$ depth during Shinkai 2000 dive 1148 at a hydrothermal vent site in the Manus Basin, Papua New Guinea, and (b) observed at $721 \mathrm{~m}$ during ROV HyperDolphin dive 294 at the Hatoma Knoll

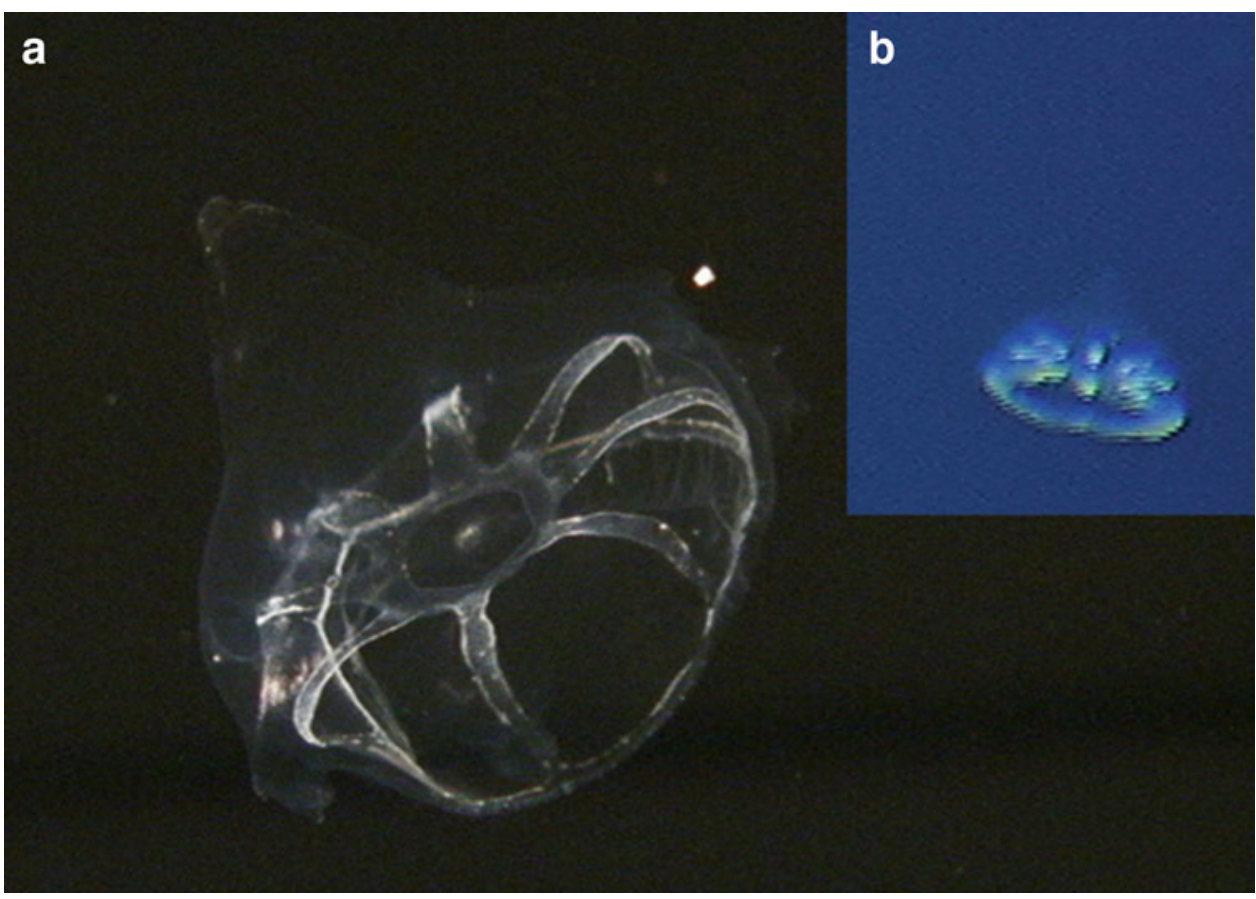

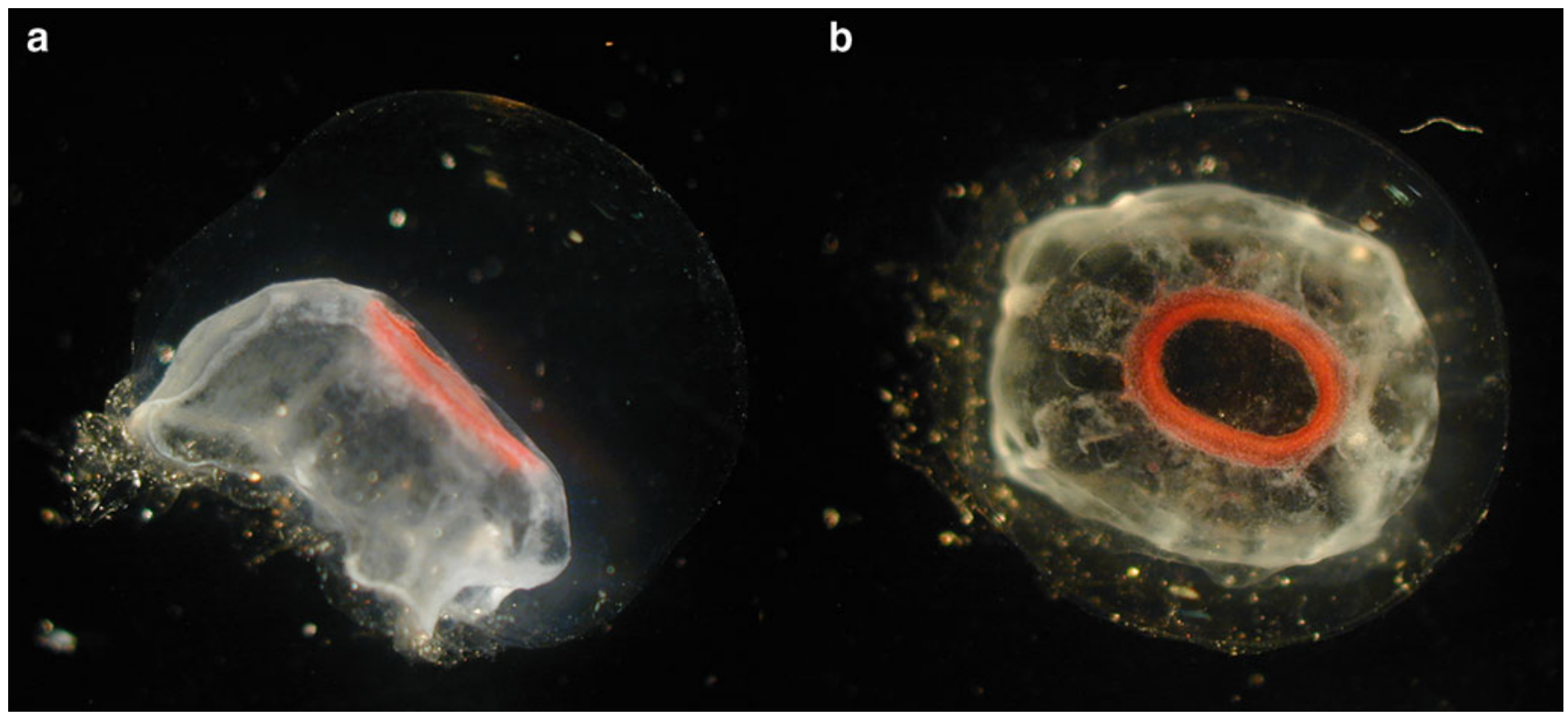

Fig. 51.24 Haliscera bigelowi in (a) lateral view, and (b) apical view, captured during Shinkai 2000 dive 1188 at $833 \mathrm{~m}$ depth

umbrella clear when juvenile, becoming orange to red with maturity; no exumbrellar nematocysts; with very strong and conspicuous musculature and circular, apical muscle-free zone (MFZ); stomach orange to red, narrow, cylindrical, no more than three-quarters of bell height; four small, simple lips; no gastric peduncle; gonads extending along greater portion of the 8 orange, narrow radial canals but not reaching apical MFZ; mature gonads contain large, milky-white eggs along their length and project into subumbrellar cavity; ring canal narrow, with no centripetal canals; 64 solid marginal tentacles all alike and with uniform structure throughout entire length, rarely 56; 64(56) free, club-shaped, marginal statocysts; velum very broad, more than one-third of bell height.

Comments: One individual (2K1183SS1A) was caught at the Hatoma Knoll during Shinkai 2000 dive 1183 at 753 m depth.

Type Material: Holotype collected southwest of Iceland. Genus Crossota Vanhöffen, 1902

Crossota millsae Thuesen 2003 (Fig. 51.26) 


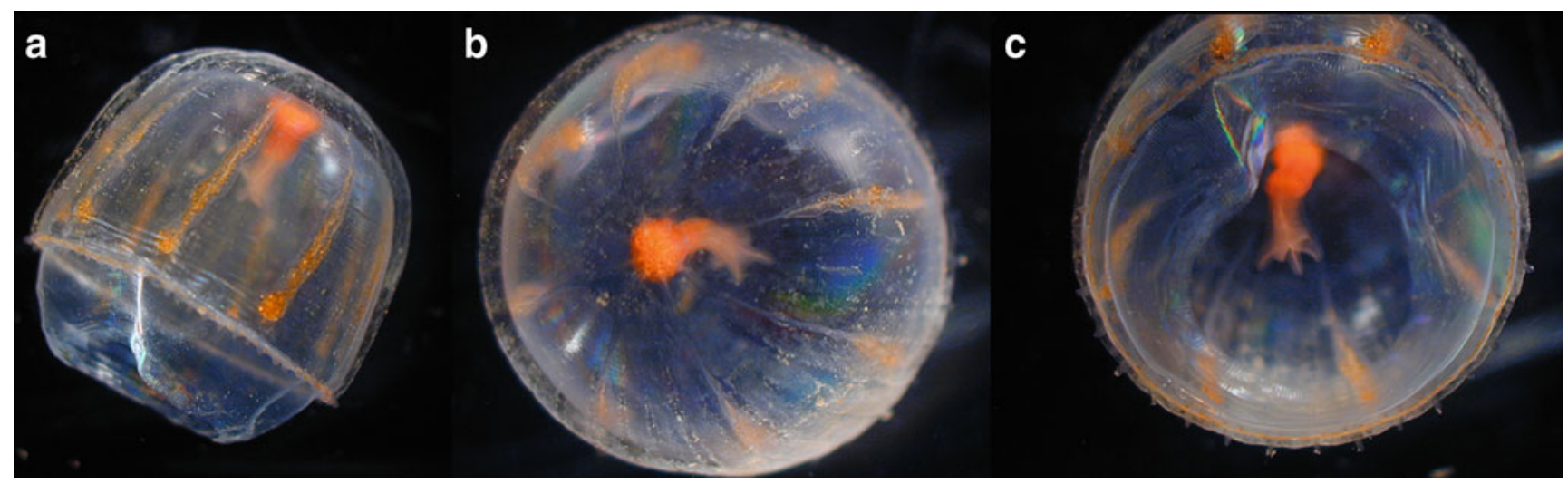

Fig. 51.25 Pantachogon haeckeli in (a) lateral view, (b) apical view, and (c) oral view, captured during Shinkai 2000 dive 1183 at $753 \mathrm{~m}$ depth

Fig. 51.26 Crossota millsae in (a) fishing/feeding position in lateral view, and (b) in apico-lateral view, observed and captured at 1,440 $\mathrm{m}$ during ROV HyperDolphin dive 296

Umbrella hemispherical, to $28 \mathrm{~mm}$ diameter and $18 \mathrm{~mm}$ height, subumbrellar surface burnt-tangerine, mesoglea colorless; without peduncle; numerous meridional exumbrellar furrows; 8 radial canals and a ring canal with no centripetal canals or expansions; "gonads" on radial canals, about $20 \%$ bell height from the manubrium, male gonads pendulous sausage-shaped, female gonads globular with eggs developing into juveniles while attached to the mother; manubrium and gonads bright pink to lavender; up to 220 densely crowded solid marginal tentacles all in one row; 16 free club-shaped ecto-endodermal statocysts.

Comments: this species is bathypelagic and widespread in distribution, having been observed during Shinkai 6500 dive 547 off the Sanriku coast (Lindsay 2005, Fig. 10, 3,668 m depth, 14:21, 8 Jun 2000), off Hawai'i, California (2,540 m and 3,244 $\mathrm{m}$ depth) and in the Sea of Cortez (Thuesen 2003), as well as from depths between 1,614 and 2,093 $\mathrm{m}$ in the Chukchi Basin, Arctic Ocean (Raskoff et al. 2010). During the present study it was observed at $1,440 \mathrm{~m}$ depth during ROV HyperDolphin dive 296.

Type Material: Holotype collected at 2,540 m depth off Monterey, California, on dive 366 of the ROV Tiburon on 2 October $2001(36.338 \mathrm{~N}, 122.901 \mathrm{~W})$ and deposited at the Smithsonian (SBMNH No. 349314).

Order Narcomedusae Haeckel, 1879

Family Cuninidae Bigelow, 1913

Genus Solmissus Haeckel, 1879

Solmissus incisa (Fewkes, 1886) (Fig. 51.27)

Umbrella up to $100 \mathrm{~mm}$ wide, flat, disk-like, with thin and flexible margin, mesoglea fairly thick but soft and fragile, exumbrella smooth; velum well developed; manubrium large, circular, covering subumbrella surface; 20-40 
Fig. 51.27 Solmissus incisa morphotypes with $(\mathbf{a}, \mathbf{b}) 23$ tentacles captured at $486 \mathrm{~m}$ depth during ROV HyperDolphin dive 296, and with (c, d) 32 tentacles captured at $896 \mathrm{~m}$ during ROV HyperDolphin dive 294

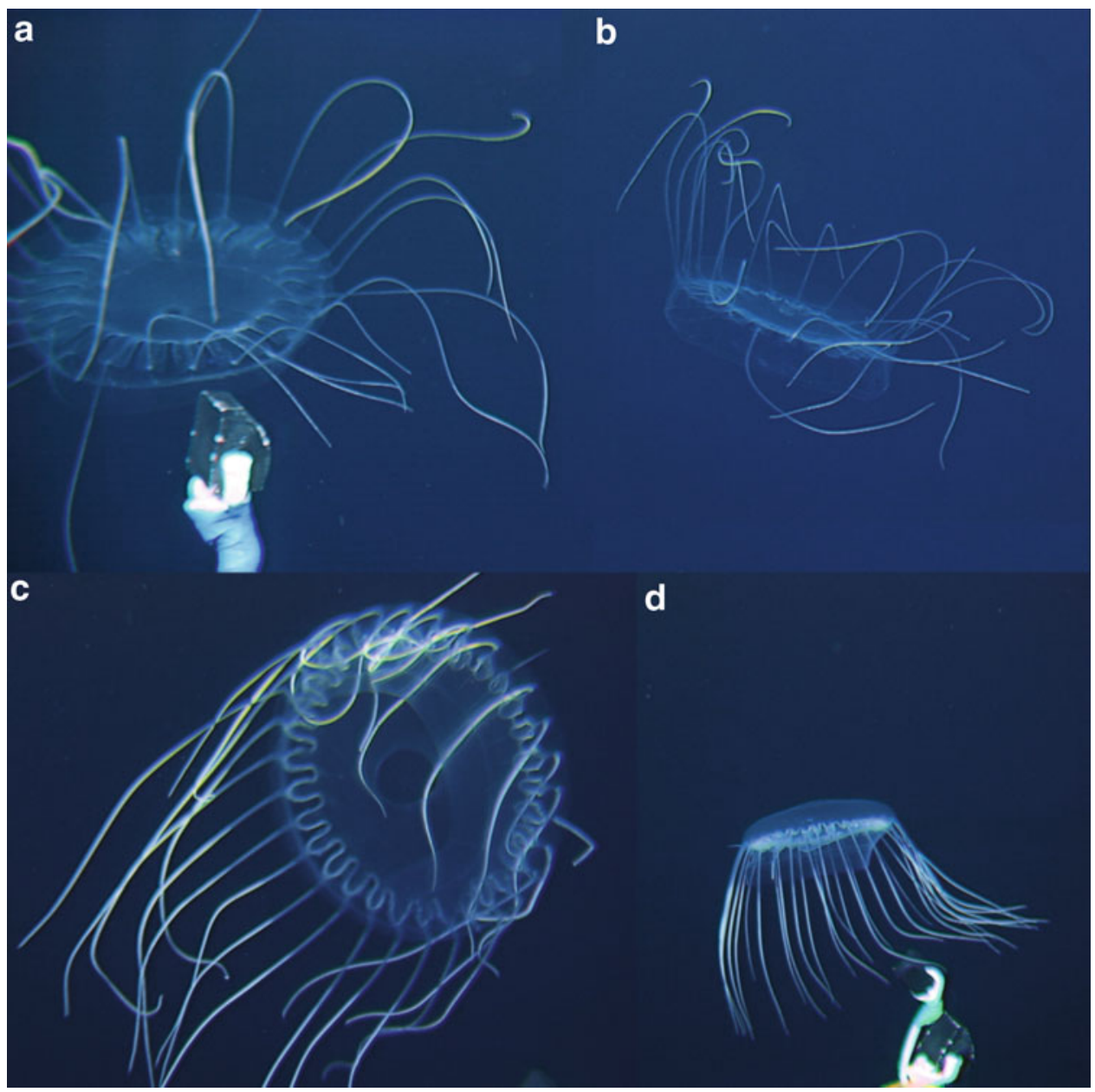

perradial manubrial pouches, oval in outline, usually somewhat longer than wide, septa between them alternating with tentacle roots; 20-40 marginal tentacles, stiff, tapering, up to slightly longer than diameter of umbrella; no peripheral canal system; gonads?; marginal lappets rectangular, about as long as broad, each with 2-5 statocysts, no otoporpae.

Comments: Several different morphotypes of this species were observed. It is likely that several cryptic species are currently being referred to under this species name. Specimens were successfully sampled at $896 \mathrm{~m}(64 \mathrm{~mm}$ diameter, 31 tentacles) during ROV HyperDolphin dive 294, and at $486 \mathrm{~m}$ depth (23 tentacles) on ROV HyperDolphin dive 296, as well as during Shinkai 2000 dive $1,183 \mathrm{~m}$ at $797 \mathrm{~m}$ depth (30 mm diameter, 31 tentacles) and dive 1188 at $770 \mathrm{~m}$ depth (2K1188GS1: $50 \mathrm{~mm}$ diameter, 32 tentacles).

Type Material: The material on which the original description was based was from several broken animals collected at $39^{\circ} 44^{\prime} 30^{\prime \prime} \mathrm{N} 71^{\circ} 04^{\prime} 00^{\prime \prime} \mathrm{E}$ (Station 2094, 1022 fathoms $=1,879 \mathrm{~m}$ ), $38^{\circ} 48^{\prime} 00^{\prime \prime} \mathrm{N} 72^{\circ} 40^{\prime} 30^{\prime \prime} \mathrm{E}$ (Station 2104 , 991 fathoms $=1,666 \mathrm{~m}), 35^{\circ} 13^{\prime} 10^{\prime \prime} \mathrm{N} 74^{\circ} 57^{\prime} 15^{\prime \prime} \mathrm{E}$
(Station 2110, surface) by the U.S. Fish Commission steamer Albatross in the region of the Gulf Stream in 1883-1884.

Family Solmarisidae Haeckel, 1879

Genus Solmaris Haeckel, 1879

Solmaris sp. of Arai, Cavey and Moore, 2000 (Fig. 51.28)

One individual of this species (2K1188SS1B), conforming to the description of Arai et al. (2000) in every respect, was collected during Shinkai 2000 dive 1188 at $806 \mathrm{~m}$ depth. As the bell rim was not intact, and it was not possible to observe the sense organs, at this time it remains impossible to clearly distinguish it from Solmaris quadrata Bouillon, Boero and Seghers, 1991. The lack of stomach pouches clearly distinguishes it from Aegina citrea and Aegina rosea, and the lack of secondary tentacles also distinguishes it from Bathykorus species. No traces of a peripheral canal system were observed flanking the peronia, thereby excluding it from the genus Pegantha. The taxonomy of the narcomedusae is muddled with at least two families being paraphyletic (Lindsay, personal observation) and it is advised that all specimens be sufficiently described 
Fig. 51.28 Solmaris sp.

collected during Shinkai 2000

dive 1188 at $806 \mathrm{~m}$ depth

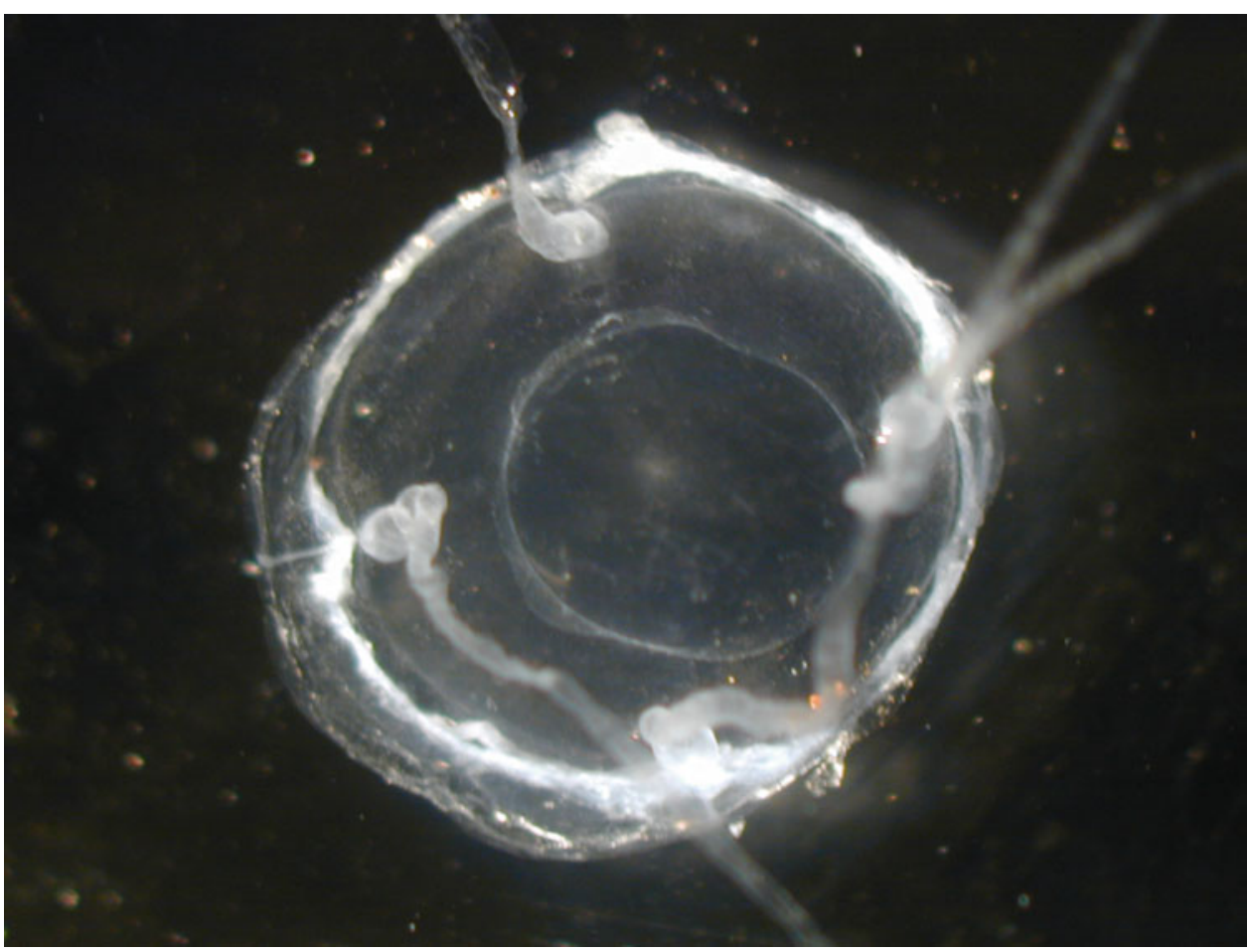

using the material at hand rather than simply referring them to existing species names, which often encompass multiple cryptic taxa.

Type Material: None, as the species has not yet been formally described. Most of Arai et al.'s specimens were collected off the west coast of Vancouver Island, British Columbia, Canada (Arai et al. 2000).

Family Aeginidae (Gegenbaur, 1857)

Genus Bathykorus Raskoff, 2010

Bathykorus? sp. A (Fig. 51.29)

A narcomedusa with four primary tentacles and four secondary tentacles, with its primary tentacles raised flush with the bell until reaching the apex and then curving sharply out at an acute angle in an "elbow" was observed (eg. HyperDolphin Dive 67, 1,192 m depth, 12:46, 18 Nov 2001, Fig. 51.29). This swimming behaviour is identical to that of an undescribed Bathykorus species that occurs off the Sanriku coast and in the vicinity of Sagami Bay (Hunt and Lindsay 1999, Fig. 5E, as "Narcomedusae sp. B"; Lindsay and Hunt 2005, Table 1, as "Aeginidae the six-tentacled one with elbows and secondary tentacles" and Table 3 as "Narcomedusae sp. A"; Kitamura et al 2008, Fig. 24.15 as "Narcomedusae gen. et sp."; Lindsay and Miyake 2009, as "Aeginidae Genus nov. Species nov."). That species, however, has up to 36 invaginations of the stomach pouches and long secondary tentacles. The sole described species of these genus, Bathykorus bouilloni Raskoff, 2010 has only three manubrial pouches and shorter secondary tentacles (Raskoff 2010). The present animal from the Hatoma
Knoll has four stomach pouches with no visible invaginations and the secondary tentacles are so small as to be easily missed during video analysis, appearing only as faint whitenings on the bell rim at the midpoint between primary tentacles. The maximum diameter recorded for $B$. bouilloni is $1.5 \mathrm{~cm}$ (Raskoff 2010) while that of the undescribed Aeginidae reported by Lindsay and Miyake (2009) was $4 \mathrm{~cm}$. The present observation from the Hatoma Knoll relies on the video record and there is no way to determine the size of the animal, except to say that it "seems smaller than the Sanriku species." It might be possible that these three forms are just ontogenetic stages of the same species with stomach pouch number and secondary tentacle length increasing with growth. However, at present because the distributions of the three forms are discontinuous and the present generic diagnosis for Bathykorus states "manubrial pouches $3 \mathrm{x}$ tentacle number (rarely more)" (Raskoff 2010) we refer to this animal from Hatoma Knoll as Bathykorus? sp.

Order Coronatae Vanhöffen, 1892

Family Atollidae Bigelow, 1913

Atolla Haeckel, 1880

Atolla wyvillei Haeckel, 1880 (Fig. 51.30)

Exumbrella flattened with deep, circular coronal furrow, jelly thickened, lenslike, slightly vaulted, with deep marginal radial furrows, to around $15 \mathrm{~cm}$ diameter, pigmented dark brownish red. Tentacles: alternating with marginal sense organs (rhopalia), usually 22 (rarely 17, 19, 20, 21, 29,32 , or 36 ), one tentacle hypertrophied. Tentacular 
a

b

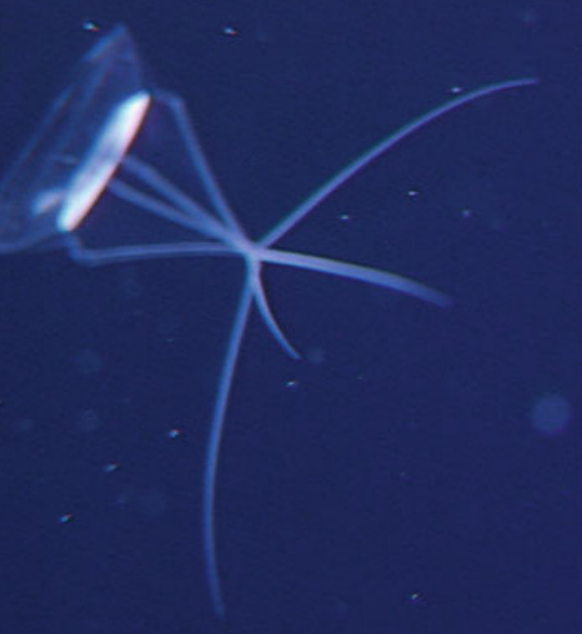

C

Fig. 51.29 Bathykorus? sp. A in (a) lateral, (b) apical, and (c) apico-lateral views, observed during ROV HyperDolphin Dive 67 at 1,192 m depth

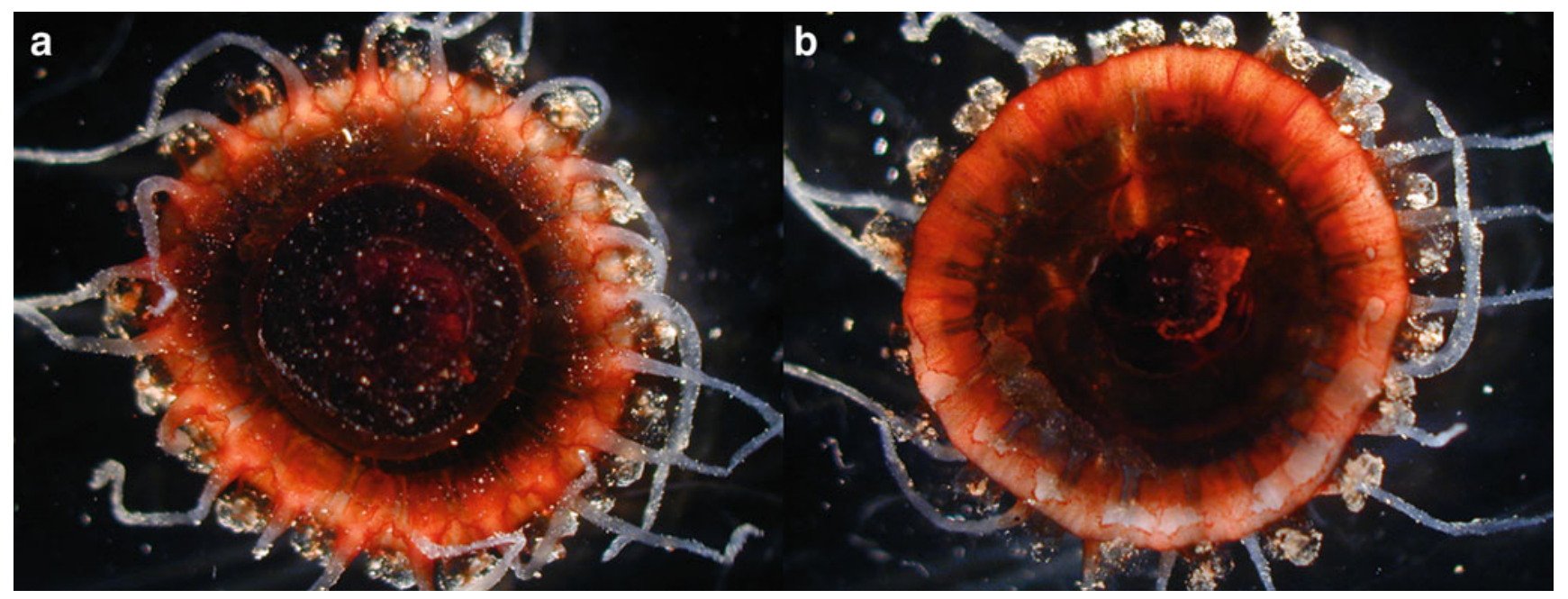

Fig. 51.30 Atolla wyvillei in (a) apical, and (b) oral views, captured at $837 \mathrm{~m}$ depth during Shinkai 2000 dive 1188

pedalia: irregular pentagonal shape, broad base. Rhopaliar pedalia: without linear ridges of warts. Lappets: long, with rounded ends. Coronal muscle: cream-colored, thick, outer portion wavy in appearance owing to radial grooves in tentacular radii. Radial septa: paired, noticeably divergent adaxially, extending beyond margin of coronal muscle. Stomach: projecting downwards from center of bell, pigmented very dark brownish red, margin with four rounded pouches in primroselike contour, no pigment spots between stomach base and gonads. Gonads: eight, adradial; cream-colored with faint orange tint, variable in form; in small specimens (less than $5 \mathrm{~cm}$ in diameter) bean-shaped, in mature specimens (greater than $5 \mathrm{~cm}$ in diameter) auriform owing to partial abaxial curling of opaque thickened gonadal margin and with central transparent region with thin tissue covering; gonad arrangement variable, with partial contact of 4 gonadal pairs in some specimens; ova: to about $1 \mathrm{~mm}$ in diameter, located in center of ovaries.

Comments: An individual (2K1188SS2) was caught at $837 \mathrm{~m}$ depth during Shinkai 2000 dive 1188.

Type Material: H.M.S. Challenger Collection. Five syntypes from $53^{\circ} 55^{\prime} \mathrm{S}, 108^{\circ} 35^{\prime} \mathrm{E}, 3$ March 1874,1950 fathoms, and $42^{\circ} 32^{\prime} \mathrm{S}, 56^{\circ} 27^{\prime} \mathrm{W}, 11$ February 1876,2040 fathoms.

Family Periphyllidae Haeckel, 1880

Periphylla F. Müller, 1861

Periphylla periphylla (Péron and Lesueur, 1810) (Fig. 51.31) 
Fig. 51.31 Periphylla periphylla collected during Shinkai 2000 dive 1188 at $751 \mathrm{~m}$ depth

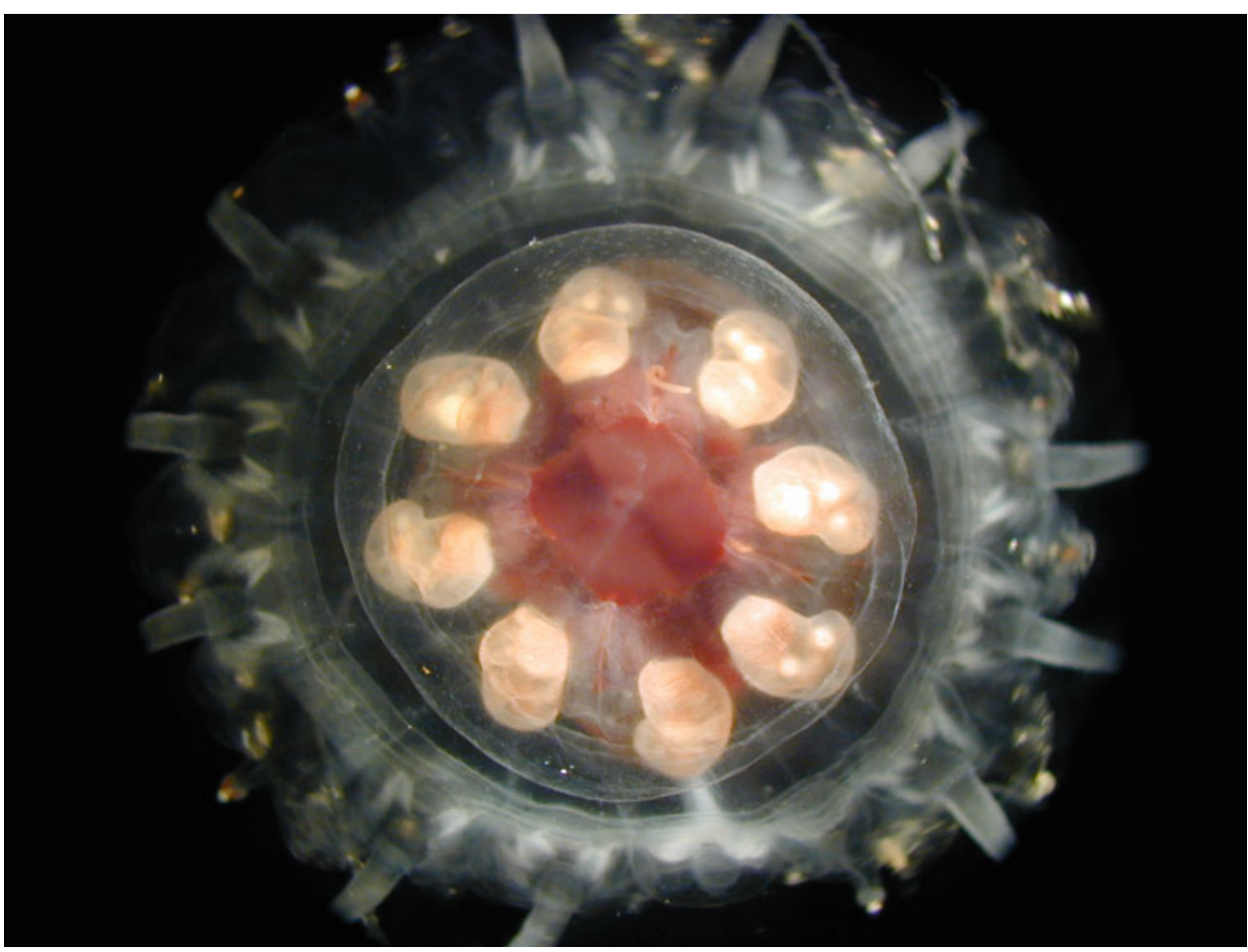

Scyphomedusa with pointed or dome-shaped exumbrella, up to $350 \mathrm{~mm}$ wide, usually higher than wide, usually transparent, sometimes with a reddish-brown ectodermis, with margin cleft into 16 lappets, with a circular, coronal furrow; four interradial sense organs (rhopalia); $12(4 \times 3)$ solid marginal tentacles (four perradial and eight adradial) arising from clefts between the lappets; gonads U- or J-shaped, in four pairs, whitish; stomach not extending beyond umbrella margin, with a single mouth opening provided with simple lips, violet or reddish-brown. Pigmentation from a protoporphyrin. Swims with tentacles held forward of the bell. Nematocyst types: holotrichous isorhizas, heterotrichous microbasic euryteles.

Comments: An individual was caught at $751 \mathrm{~m}$ depth during Shinkai 2000 dive 1188.

Type Material: from equatorial Atlantic Ocean, Baudin Expedition.

Acknowledgments This work was partially funded by JSPS grant KAKENHI, (24248032, 23405031), MEXT Grant-in-Aid for Scientific Research on Innovative Areas TAIGA (20109003), and JST grant CREST, the fund for Interdisciplinary Collaborative Research by the AORI, UT.

Open Access This chapter is distributed under the terms of the Creative Commons Attribution Noncommercial License, which permits any noncommercial use, distribution, and reproduction in any medium, provided the original author(s) and source are credited.

\section{References}

Arai MN, Cavey MJ, Moore BA (2000) Morphology and distribution of a deep-water Narcomedusa (Solmarisidae) from the northeast Pacific. Sci Marina 64(1):55-62

Bone Q (1998) Biology of pelagic tunicates. Oxford University Press, New York, 340

Burd BJ, Thomson RE (2000) Distribution and relative importance of jellyfish in a region of hydrothermal venting. Deep Sea Res I 47:1703-1721

Haddock SHD, Case JF (1999) Bioluminescence spectra of shallow and deep-sea gelatinous zooplankton: ctenophores, medusae and siphonophores. Mar Biol 133:571-582

Hunt JC, Lindsay DJ (1999) Methodology for creating an observational database of midwater fauna using submersibles: results from Sagami Bay, Japan. Plank Biol Ecol 46(1):75-87

Johnsen S (2005) The red and the black: bioluminescence and the color of animals in the deep sea. Integr Comp Biol 45:234-246

Kitamura M, Miyake H, Lindsay DJ (2008) Cnidaria. In: Fujikura K, Okutani T, Maruyama T (eds) Deep-sea life - biological observations using research submersibles. Tokai University Press, Kanagawa, pp 295-320

Kovacs D, Madin K (1996) Beneath Blue Waters: Meetings with Remarkable Deep-sea Creatures. Viking Children's Books, 64 pp

Lindsay DJ (2003) Bioluminescence in the mesopelagic realm, Kaiyo Month Spec Edit 35(9):606-612

Lindsay DJ (2005) Planktonic communities below 2,000 m depth. Bull Plank Soc Jpn 52(2):113-118

Lindsay DJ, Hunt JC (2005) Biodiversity in midwater cnidarians and ctenophores: submersible-based results from deep-water bays in the Japan Sea and North-western Pacific. J Mar Biol Assoc UK 85 (3):503-517 
Lindsay DJ, Miyake H (2007) A Novel Benthopelagic Ctenophore from 7,217 m depth in the Ryukyu Trench, Japan, with notes on the taxonomy of deep sea cydippids. Plank Benthos Res 2(2):98-102

Lindsay DJ, Miyake H (2009) A checklist of midwater cnidarians and ctenophores from Japanese waters -species sampled during submersible surveys from 1993-2008 with notes on their taxonomy. Kaiyo Month 41(8):417-438

Lindsay DJ, Hunt JC, Hashimoto J, Fujiwara Y, Fujikura K, Miyake H, Tsuchida S (2000) Submersible observations on the deep-sea fauna of the south-west Indian Ocean: preliminary results for the mesopelagic and near-bottom communities. JAMSTEC J Deep Sea Res $16: 23-33$

Madin LP, Harbison GR (1978a) Bathocyroe fosteri gen. nov., sp. nov.: a mesopelagic ctenophore observed and collected from a submersible. J Mar Biol Assoc UK 58:559-564

Madin LP, Harbison GR (1978b) Thalassocalyce inconstans, new genus and species, an enigmatic ctenophore representing a new family and order. Bull Mar Sci 28(4):680-687

Raskoff K (2010) Bathykorus bouilloni: a new genus and species of deep-sea jellyfish from the Arctic Ocean (Hydrozoa, Narcomedusae, Aeginidae). Zootaxa 2361:57-67

Raskoff KA, Hopcroft RR, Kosobokova KN, Purcell JE, Youngbluth M (2010) Jellies under ice: ROV observations from the Arctic 2005 hidden ocean expedition. Deep-Sea Res II 57:111-126
Skebo K, Tunnicliffe V, Berdeal IG, Johnson HP (2006) Spatial patterns of zooplankton and nekton in a hydrothermally active axial valley on Juan de Fuca Ridge. Deep-Sea Res I 53:1044-1060

Stechow E (1919) Zur Kenntnis der Hydroidenfauna des Mittelmeeres, Amerikas und anderer Gebiete, nebst Angaben über einige Kirchenpauer'sche Typen von Plumulariden. Zool Jb Syst 42(1)1-172.

Thuesen EV (2003) Crossota millsae (Cnidaria: Trachymedusae: Rhopalonematidae), a new species of viviparous hydromedusa from the deep sea off California and Hawaii. Zootaxa 309:1-12

Toyokawa M, Toda T, Kikuchi T, Miyake H, Hashimoto J (2003) Direct observations of a dense occurrence of Bolinopsis infundibulum (Ctenophora) near the seafloor under the Oyashio and notes on feeding behavior. Deep-Sea Res I 50:809-813

Vereshchaka AL, Vinogradov GM (1999) Visual observations of the vertical distribution of plankton throughout the water column above the Broken Spur vent field Mid-Atlantic Ridge. Deep-Sea Res I 46:1615-1632

Vinogradov ME, Shushkina EA (2002) Vertical distribution of gelatinous macroplankton in the North Pacific observed by manned submersibles Mir-1 and Mir-2. J Oceanogr 58:295-303

Youngbluth M, Sørnes T, Hosia A, Stemmann L (2008) Vertical distribution and relative abundance of gelatinous zooplankton, in situ observations near the Mid-Atlantic Ridge. Deep-Sea Res II $55: 119-125$ 